\title{
O Primado do Mercado Interno - A Proeminência do Espaço Canavieiro de Minas Gerais no Último Século de Hegemonia das Atividades Agroaçucareiras Tradicionais no Brasil ${ }^{\star}$
}

- Marcelo MagalHães Godoy*

\begin{abstract}
RESUMO
Minas Gerais foi, durante o século 19 e início da centúria seguinte, o mais importante espaço canavieiro do Brasil. Para a década de 1830, estima-se a existência em Minas de 4.150 unidades produtivas com transformação da cana-de-açúcar. A soma dos engenhos do litoral nordestino, do norte fluminense e do Planalto Paulista não alcançava a metade do número de engenhos mineiros. Para este mesmo período, estima-se que em Minas 85 mil cativos eram empregados na fabricação de açúcar e aguardente. Em nenhum outro espaço canavieiro, em qualquer período da história do Brasil escravista, foi empregado contingente desta magnitude. Ainda para a quarta década do Oitocentos, estima-se que Minas Gerais produzia 33.200 toneladas de açúcar. A produção paulista não superava 8.500 toneladas e a de Pernambuco era de 27 mil. As exportações de açúcar da Bahia não perfaziam 30 mil toneladas, e as do Rio de Janeiro não alcançavam 17 mil.
\end{abstract}

\section{Palavras-Chave}

atividades agroaçucareiras, mercado interno, Minas Gerais - Brasil, séculos 19 e 20

\section{ABSTRACT}

During 19th century and the beginning of the following century, Minas Gerais was the most important sugarcane plantation area in Brazil. In the 1830's, there were 4.150 productive unities working with sugarcane transformation in Minas. The sum of all sugar mills in the northeast coast, north of Rio de Janeiro and the plains of São Paulo did not reach half of the number of sugar mills in Minas Gerais. In the same period, it is estimated that 85.000 captives was employed in the fabrication of sugar and of aguardente. That such a large contingent had neither been employed in any other sugarcane plantation area nor in any other period of brazilian slavery history. Furthermore, it is estimated that in the 1830's Minas Gerais produced 33.200 tons of sugar. The sugar production of São Paulo did not surpass 8.500 tons, and the production of Pernambuco was 27.000. The sugar exportation of Bahia was not more than 30.000 tons and the amount exported by Rio de Janeiro did not reach 17.000 .

\section{KEYWORDS}

sugar plantation activities, domestic market, Minas Gerais - Brazil, 19th and 20th centuries

\author{
JEL CLASSIFICATION \\ NOI, N36, N56, N96
}

\footnotetext{
+ Este texto é versão adaptada e significativamente ampliada de tópico da tese de doutorado: No país das minas de ouro a paisagem vertia engenhos de cana e casas de negócio - Um estudo das atividades agroaçucareiras tradicionais mineiras, entre o Setecentos e o Novecentos, e do complexo mercantil da província de Minas Gerais (GODOY, 2004, p. 525-557).

* Doutor em História Econômica pela Universidade de São Paulo. Professor do Departamento de Ciências Econômicas e pesquisador do Centro de Desenvolvimento e Planejamento Regional da Faculdade de Ciências Econômicas da Universidade Federal de Minas Gerais. Pesquisador associado ao Núcleo de Pesquisa em História Econômica e Demográfica do Cedeplar/UFMG. Endereço para correspondência: Cedeplar/Face/UFMG: Av. Antônio Carlos, 6627 - Belo Horizonte/MG - CEP: 31270-091. E-mail: mmgodoy@cedeplar.ufmg.br.
}

(Recebido em maio de 2007. Aceito para publicação em abril de 2008). 


\section{INTRODUÇÃO}

Minas Gerais foi, durante o século 19 e início da centúria seguinte, o mais importante espaço canavieiro do Brasil. Para a década de 1830, estima-se a existência em Minas de 4.150 unidades produtivas com transformação da cana-de-açúcar. A soma de todos os engenhos do litoral nordestino, do norte fluminense e do Planalto Paulista, as principais regiões produtoras de açúcar para mercados externos, não alcançava a metade do número de engenhos mineiros. Para este mesmo período, estima-se que $40 \%$ da força de trabalho escrava de Minas Gerais, ou mais de 85 mil cativos, era empregada, sazonalmente, na fabricação de açúcar, rapadura e aguardente. É grande a probabilidade de que em nenhum outro espaço canavieiro, em qualquer período da história do Brasil escravista, tenha sido empregado contingente desta magnitude. Ainda para a quarta década do Oitocentos, estima-se que Minas produzia 33.200 toneladas de açúcar e rapadura e mais de 22 milhões de litros de aguardente. As exportações de açúcar da Bahia não perfaziam 30 mil toneladas, as do Rio de Janeiro não alcançavam 17 mil e Alagoas e Sergipe exportavam juntas menos de 6 mil toneladas. As informações disponíveis indicam que a produção paulista de açúcar não superava 8.500 toneladas e a de Pernambuco estava em torno de 27 mil. Estas evidências são especialmente surpreendentes se considerados os atributos fundamentais da economia canavieira de Minas Gerais: desconcentração espacial da produção, diversificada base técnica, variadas configurações no tamanho e composição da força de trabalho, múltiplas escalas de produção, sazonalidade, consorciação do cultivo e transformação da cana com outras atividades econômicas e, especialmente, produção para o mercado interno (GODOY, 2004, p. 22-79).

\section{ESTIMATIVA DO NÚMERO DE ENGENHOS DE CANA}

Os Mapas de Engenhos Aguardenteiros e Casas de Negócio de 1836 forneceram os principais dados que permitiram a construção de estimativa do número de engenhos de cana da província de Minas Gerais. A Lei de 8 de abril de 1836 estabeleceu a fabricação de aguardente como condição para a incidência do novo tributo. O Ofício de 16 de junho de 1836, enviado aos distritos de paz, definiu os engenhos aguardenteiros ou que fabricavam aguardente como objeto do inventário solicitado (Ibidem, p. 186-248). ${ }^{1}$ Entretanto, nem todas as autoridades locais se limitaram a atender

1 Em 1836, foi criado novo tributo para os setores canavieiro e comercial de Minas Gerais. Os referidos mapas cumpriram o objetivo de inventariar o universo de contribuintes da província. Documentação fiscal, os Mapas de engenhos aguardenteiros e casas de negócio de 1836 conformam as mais extensas e detalhadas relaçốes nominais de proprietários de engenhos de cana e estabelecimentos comerciais do Oitocentos mineiro. Para os engenhos foram informados regularmente o nome e sobrenome dos engenheiros bem como a força motriz dos equipamentos de moagem. Além dessas informações, os responsáveis pelos mapas acrescentaram, irregularmente, uma miríade de informações não solicitadas, como: 
o disposto na Lei e Ofício. Aproximadamente 7\% dos engenhos relacionados nos Mapas de 1836 não fabricavam aguardente: dedicavam-se exclusivamente à elaboração de rapadura e/ou açúcar. A princípio, vislumbram-se três plausíveis razões para o arrolamento destas unidades: 1 . incompreensão da portaria e da lei, com a decorrente listagem de todos os engenhos, independente dos derivados produzidos; 2. excesso de zelo e o rigoroso inventário de todas as unidades transformadoras da cana; 3 . tentativa de encobrimento de reconhecido engenheiro aguardenteiro, apresentado como exclusivamente rapadureiro e/ou açucareiro.

Breve estudo desse universo de engenhos não-aguardenteiros conduziu à conclusão de que o entendimento distorcido do ofício de 16 de junho e da lei de 8 de abril e/ ou o excesso de diligência na declaração dos engenhos são as razões mais prováveis para o arrolamento de engenhos exclusivamente rapadureiros e/ou açucareiros. Esses engenhos foram listados em 35 distritos, ou 12\% dos mapas remanescentes, que se distribuíam por 12 das 16 regiões de Minas Gerais com efetiva ocupação (Idem, 1996). Nesses 35 distritos foram arrolados 311 engenhos, ou 16\% de todos os engenhos relacionados na documentação de 1836. Entretanto, e aí reside forte evidência a desqualificar a terceira razão - a do encobrimento de engenhos aguardenteiros -, nesses distritos foram arrolados quase $60 \%$ de todos os engenhos de $1836 \mathrm{com}$ produção mista, ou seja, aguardente mais açúcar e/ou rapadura. Se a intenção fosse simplesmente ocultar a produção de aguardente, não teria sido listado número relativamente tão elevado de engenhos que fabricavam múltiplos derivados. A natural decorrência desta constatação é o estabelecimento da confiabilidade dos dados arrolados nesses mapas atípicos, apenas frutos do mencionado entendimento distorcido e do referido excesso de diligência.

A distribuição destes engenhos segundo os derivados fabricados evidencia o equilíbrio entre os que produziam aguardente e aqueles que elaboravam rapadura e/ ou açúcar. Os engenhos de produção mista eram aproximadamente $50 \%$ menos incidentes do que os especializados, sejam os exclusivamente aguardenteiros, sejam os unicamente rapadureiros e/ou açucareiros. Considerados em separado, pouco mais de dois terços dos engenhos que fabricavam aguardente eram exclusivamente produtores do destilado.

composição da força de trabalho, escala da produção, derivados elaborados e destino da produção. A representatividade e cobertura dos mapas remanescentes são excepcionais, abarcam aproximadamente $71 \%$ dos distritos, e a população correspondente supera 76\% (GODOY, 2004, p. 186-248). 


\begin{tabular}{|c|c|c|c|c|}
\hline \multirow{2}{*}{ Derivados fabricados } & \multicolumn{2}{|c|}{ Engenhos } & \multicolumn{2}{|c|}{ Engenhos aguardenteiros } \\
\hline & № & $\%$ & № & $\%$ \\
\hline Rapadura e/ou açúcar & 126 & 40,5 & -- & -- \\
\hline Aguardente & 126 & 40,5 & 126 & 68,1 \\
\hline Aguardente e rapadura e/ou açúcar & 59 & 19,0 & 59 & 31,9 \\
\hline Total & 311 & 100,0 & 185 & 100,0 \\
\hline
\end{tabular}

Fonte: Arquivo Público Mineiro: SPPPl/6, diversas caixas.

Se dos 1.935 engenhos arrolados nos 297 mapas remanescentes (Idem, 2004, p. 417 ) forem subtraídos os 134 engenhos não-aguardenteiros (126 rapadureiros e/ ou açucareiros, mais 8 casos indefinidos), resultam 1.801 unidades que produziam o destilado. Considerada a mesma proporção encontrada para os documentos com engenhos produtores de todos os derivados, dividiam-se estas unidades em 1.225 (68\%) exclusivamente aguardenteiras e 576 (32\%) que, além do destilado, produziam rapadura e/ou açúcar. Ainda com base na distribuição para os documentos com arrolamento de todos os engenhos, deveriam ser acrescentadas ao universo de engenhos dos distritos com documentação remanescente mais 1.225 unidades rapadureiras e/ ou açucareiras e que não fabricavam aguardente (destas foram relacionados somente 126 casos). Assim, para os 297 distritos que compõem os Mapas de 1836, e que representavam $70 \%$ do total de distritos existentes em Minas Gerais, existiriam 3.026 engenhos.

Dada a representatividade dos 311 engenhos relacionados na Tabela 1 , considerouse que, em todas as regiões de Minas Gerais, $40,5 \%$ dos engenhos fabricavam exclusivamente aguardente, 40,5\% elaboravam somente rapadura e/ou açúcar e 19\% produziam os três derivados ou pelo menos o destilado e um tipo de açúcar. Com estes dados para os 297 distritos com mapas remanescentes, foi estimado o número de engenhos para os restantes 122 distritos, totalizando o número de unidades produtivas com cultivo e transformação da cana dos 419 distritos existentes em Minas na década de 1830 (Ibidem, p.679-697). Assim, as estimativas regionais foram elaboradas tendo por base o número de engenhos aguardenteiros de 1836, os respectivos números estimados de engenhos rapadureiros e/ou açucareiros e de engenhos mistos, o número de distritos cobertos pelos mapas sobreviventes e o número total de distritos (Ibidem, p. 527-531). Portanto, a partir desse ponto foram necessários 
os seguintes procedimentos, que permitiram estimar o número de engenhos de cada região de Minas Gerais e, por decorrência, do conjunto da província:

1. Foram segmentados pelas 18 regiões de Minas Gerais os 1.801 engenhos exclusivamente aguardenteiros relacionados nos Mapas de 1836; para a região Extremo Noroeste não foi arrolada nenhuma unidade.

2. Com base na distribuição apresentada na tabela anterior, foram separados para cada região os engenhos exclusivamente aguardenteiros dos engenhos que fabricavam o destilado e também rapadura e/ou açúcar; ou seja, 68\% dos engenhos foram considerados exclusivamente produtores de aguardente e os 32\% restantes entendidos aguardenteiros e também rapadureiros e/ou açucareiros. Exemplo: na região Mineradora Central Oeste, onde foram listados 410 engenhos aguardenteiros, considerou-se que, destes, 279 (68\%) eram fabricantes de aguardente e 131 (32\%) eram fábricas que combinavam a produção do destilado com a elaboração de rapadura e/ou açúcar.

3. Também fundamentado na distribuição verificada na tabela anterior, para cada região foram acrescentadas como engenhos exclusivamente rapadureiros e aguardenteiros o mesmo número de unidades apuradas como unicamente aguardenteiras. Exemplo: na região do Vale do Médio-Baixo Rio das Velhas foram listados 140 engenhos aguardenteiros e considerou-se que, destes, 95 eram fabricantes de aguardente e 45 combinavam a produção do destilado com a elaboração de rapadura e/ou açúcar; somaram-se mais 95 engenhos que produziriam exclusivamente rapadura e/ou açúcar, totalizando 235 unidades com cultivo e transformação da cana.

4. Realizados estes procedimentos para todas as regiões, obteve-se a distribuição regional do número de engenhos segundo os derivados da cana-de-açúcar produzidos para os 297 distritos com Mapas de 1836 remanescentes; o próximo passo foi estabelecer o número de engenhos segundo os derivados produzidos para os 419 distritos de paz existentes em Minas Gerais na primeira metade da década de 1830; para tanto, calculou-se o número médio de engenhos por distrito e segundo os derivados produzidos para cada região, com base nos dados disponíveis para os distritos com mapas remanescentes e, em seguida, multiplicou-se esse número médio pelo número total de distritos existentes. Exemplo: na região Sudeste, foram listados 91 engenhos aguardenteiros nos 38 distritos com Mapas de 1836 remanescentes; 62 foram considerados exclusivamente fabricantes do destilado e 29 definidos como fábricas que combinavam a elaboração da aguardente com a produção de rapadura e/ou açúcar, e acrescentados mais 62 engenhos unicamente rapadureiros e/ou açucareiros, totalizando 153 unidades com 
cultivo e transformação da cana; para encontrar o número de engenhos segundo os derivados produzidos para os 46 distritos existentes na região, procedeu-se da seguinte forma:

a. tomou-se a média de 1,63 engenho exclusivamente aguardenteiro por distrito e multiplicou-se essa média pelos 46 distritos, resultando em 75 unidades que fabricavam apenas aguardente;

b. considerou-se a média de 0,76 engenho com produção mista por distrito e multiplicou-se a média considerada pelos mesmos 46 distritos, resultando em 35 unidades que fabricavam aguardente e também rapadura e/ou açúcar;

c. como no caso dos engenhos exclusivamente aguardenteiros, tomou-se a média de 1,63 engenho unicamente rapadureiro e/ou açucareiro por distrito, multiplicando-se a média pelos 46 distritos, resultando em 75 unidades que fabricavam apenas rapadura e/ou açúcar;

d. a soma das três modalidades de engenhos, segundo o derivado da cana produzido, resultou em 185 unidades com cultivo e transformação da cana, para os 46 distritos existentes na região Sudeste na primeira metade da década de 1830 .

A Tabela 2 apresenta estimativa regionalizada dos engenhos de cana de Minas Gerais. Foram estimadas 4.150 unidades com cultivo e transformação da cana, número que se coaduna com o cálculo apresentado pelo presidente da província em 1845 . $^{2}$ Entretanto, o exame do texto da Fala dirigida à Assembléia Legislativa sugere que o número de engenhos provavelmente era muito maior. ${ }^{3} \mathrm{O}$ presidente declarou ter dados para 28 dos 42 municípios da província. Faltavam, portanto, informações para um terço das municipalidades. Se os 4.429 engenhos forem divididos pelos respectivos 28 municípios, resultará média de 158 unidades produtivas com cultivo e transformação da cana por município. Se considerada a mesma média para os 14 municípios que não enviaram a "relação dos engenhos", resultam mais 2.212 unidades. Somados aos dados referidos por Quintiliano, a província de Minas Gerais apresentaria 6.641 engenhos de cana. Estas evidências sugerem duas interpretações não excludentes.

2 "Em 1845, o presidente da provincia, baseado nos dados que the foram enviados por autoridades com exercicio nos municipios, calculava haver em Minas Gerais cerca de 5 mil engenhos. Somando os algarismos que tinba em mão, Quintiliano José da Silva encontrou 4.429 engenhos. Não tendo respondido 14 municípios, e achando que somariam no minimo 571, Quintiliano arredondou para 5 mil a totalidade dos engenhos de cana de Minas Gerais” (COSTA FILHO, 1963, p. 193).

3 "Pela relação dos engenhos que exigi dos delegados de Polícia se conhece que só em 28 Muncipios, que ja se achão lançados no Mappa, se contão 4:429 engenhos: nos 14 que faltão devem pelo menos haver 571, e por isso creio que não exagero, quando conto haver na Provincia pelo menos 5:000 Engenhos” (SILVA, 1846, p. 112). 
A primeira explicação é que entre 1836 e 1845, portanto em intervalo inferior a dez anos, processou-se acelerada expansão do número de engenhos de cana da província. Em 1836, os 28 municípios de Minas Gerais apresentavam média de 148 engenhos, totalizando 4.150 unidades. Entre meados da década de 1830 e meados do decênio seguinte, foram criados 14 novos municípios. Entretanto, o ritmo acentuado de crescimento do número de unidades produtivas com cultivo e transformação da cana-deaçúcar permitiu substantiva elevação do número médio de engenhos por municipalidade, ou 158 engenhos para 42 municípios, totalizando 6.641 unidades.

A segunda interpretação baseia-se na suposição de que, em 1836, ano de criação do novo imposto incidente sobre as atividades agroaçucareiras, as autoridades da província responsáveis pelo arrolamento dos engenhos, inclusive aquelas que listaram todas as unidades, independente dos derivados fabricados, não incluíram os microengenhos por não produzirem aguardente ou pela insignificância da produção de aguardente ou de outros derivados. Com quase dez anos de vigência do imposto, em 1845 a realidade era outra. Não só as autoridades municipais provavelmente detinham conhecimento mais refinado das atividades agroaçucareiras locais, mas, sobretudo, são fortes as evidências de que o referido "Mappa" mencionado por Quintiliano resultava de intenção que se traduziria imediatamente depois em alteração significativa na base de contribuintes do tributo sobre os engenhos de cana. Em 1846, a fórmula tributária foi alterada, não somente com a inclusão dos engenhos que fabricavam rapadura e açúcar, mas também com alíquota específica para "engenhocas” de rapadura (Ibidem, p. 161).

A distribuição dos engenhos apresentada na Tabela 2 e no Mapa 1 revela forte concentração regional. Sete regiões contíguas do centro e sul da província respondiam por quase três quartos das unidades com cultivo e transformação da cana. As unidades produtivas com atividades agroaçucareiras estavam concentradas nos espaços regionais mais populosos (Ibidem, p. 245) e de ocupação mais antiga (Ibidem, p. 415-418). Constata-se, portanto, histórica correlação entre determinantes demográficas e o desenvolvimento das atividades agroaçucareiras de Minas Gerais. Esta correspondência será rompida apenas no século 20, quando a modernização tecnológica reduziu significativamente a importância da produção tradicional de derivados da cana (Ibidem, p. 82-111). 


\section{TABELA 2- ESTIMATIVA REGIONAL DO NÚMERO DE ENGENHOS DE CANA, MINAS GERAIS, 1836}

\begin{tabular}{|c|c|c|c|c|c|}
\hline \multirow[t]{2}{*}{ Regiões } & \multirow[t]{2}{*}{$\begin{array}{c}\text { Engenhos } \\
\text { aguardenteiros }\end{array}$} & \multirow{2}{*}{$\begin{array}{l}\text { Engenhos } \\
\text { rapadureiros e/ou } \\
\text { açucareiros }\end{array}$} & \multirow{2}{*}{$\begin{array}{l}\text { Engenhos } \\
\text { aguardenteiros e } \\
\text { rapadureiros e/ou } \\
\text { açucareiros }\end{array}$} & \multicolumn{2}{|c|}{$\begin{array}{l}\text { Total de } \\
\text { engenhos }\end{array}$} \\
\hline & & & & № & $\%$ \\
\hline Vale do Alto-Médio Rio São Francisco & 44 & 44 & 20 & 108 & 2,6 \\
\hline Sertão & 26 & 26 & 12 & 64 & 1,5 \\
\hline Minas Novas & 137 & 137 & 65 & 339 & 8,2 \\
\hline Triângulo & 27 & 27 & 13 & 67 & 1,6 \\
\hline Araxá & 31 & 31 & 15 & 76 & 1,8 \\
\hline Paracatu & 10 & 10 & 4 & 24 & 0,6 \\
\hline Sertão do Alto São Francisco & 29 & 29 & 14 & 71 & 1,7 \\
\hline Sertão do Rio Doce & 1 & 1 & 0 & 2 & 0,0 \\
\hline Diamantina & 15 & 15 & 7 & 36 & 0,9 \\
\hline Vale do Médio-Baixo Rio das Velhas & 127 & 127 & 60 & 314 & 7,6 \\
\hline Intermediária de Pitangui-Tamanduá & 241 & 241 & 113 & 595 & 14,3 \\
\hline Mineradora Central Oeste & 430 & 430 & 202 & 1.062 & 25,6 \\
\hline Mineradora Central Leste & 202 & 202 & 95 & 500 & 12,0 \\
\hline Mata & 97 & 97 & 46 & 239 & 5,8 \\
\hline Sudeste & 75 & 75 & 35 & 185 & 4,5 \\
\hline Sul Central & 140 & 140 & 66 & 347 & 8,4 \\
\hline Sudoeste & 49 & 49 & 23 & 121 & 2,9 \\
\hline Minas Gerais & 1.680 & 1.680 & 790 & 4.150 & 100,0 \\
\hline
\end{tabular}

Fonte: Arquivo Público Mineiro: SPPPI/6, diversas caixas. 


\section{MAPA 1 - ESTIMATIVA REGIONAL DO NÚMERO DE ENGENHOS DE CANA - MINAS GERAIS - BRASIL - 1836}

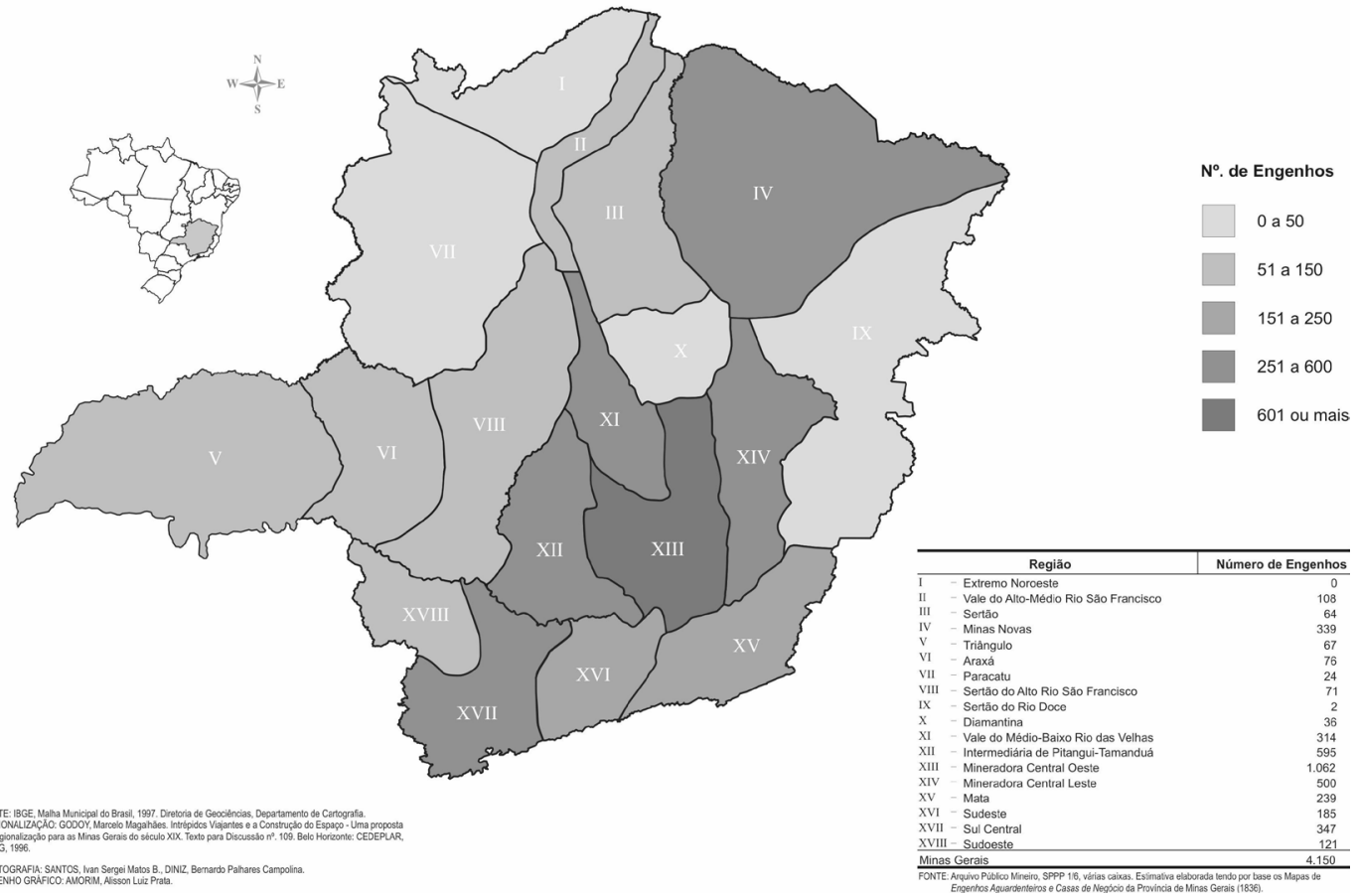

A Tabela 3 permite comparar a estimativa para Minas Gerais com dados compilados para outras províncias. A soma dos engenhos de cana - inclusive as unidades que produziam para o mercado interno - das seis províncias tradicionalmente associadas com o cultivo e transformação da cana não alcançava o número de engenhos de Minas Gerais (Ibidem, p. 530-531).

TABELA 3 - NÚMERO DE ENGENHOS DE CANA DOS PRINCIPAIS ESPAÇOS CANAVIEIROS DO BRASIL, 1836-1852

\begin{tabular}{lcc}
\hline Espaço canavieiro & Ano & Número de engenhos \\
\hline Minas Gerais & 1836 & 4.150 \\
Pernambuco & 1844 & 925 \\
Alagoas & 1849 & 316 \\
Sergipe & 1838 & 445 \\
Bahia & 1833 & 603 \\
Rio de Janeiro & 1852 & 788 \\
São Paulo & 1836 & 901 \\
\hline
\end{tabular}

Fonte: Pernambuco (EISENBERG, 1977, p. 147); Alagoas (SANT’ANNA, 1970, p. 230); Sergipe (MOTT, 1986, p.136); Bahia (MATTOSO,1992, p. 462); Rio de Janeiro (LOBO,1978, p. 265); São Paulo (PETRONE, 1968, p. 37-53). 


\section{ESTIMATIVA DO NÚMERO DE ESCRAVOS EMPREGADOS NO SETOR CANAVIEIRO}

No século 19 vigorava, em Minas Gerais, forte associação entre atividades agroaçucareiras e escravidão. Os cativos estavam presentes em $96 \%$ das unidades com cultivo e transformação da cana, freqüência média de 21,4 escravos por fogo com engenho (Ibidem, p.421-424). Considerado o caráter escravista da produção de derivados da cana, estima-se o número de escravos empregados no setor canavieiro da província. A estimativa fundamenta-se no cruzamento do número médio de escravos dos fogos com engenhos, segundo o Censo de 1831-32 (Ibidem, p.422), com o número de engenhos estimado com base nos Mapas de 1836.

O caráter da economia canavieira de Minas impôs o dimensionamento do grau de mobilização dos escravos na safra. Considerada a diversificação das unidades com atividades agroaçucareiras e a sazonalidade da elaboração dos derivados, restava conhecer por quanto tempo e em que medida os cativos concentravam-se na fabricação de aguardente, rapadura e açúcar. Evidências qualitativas afirmam variação no tamanho da safra dos engenhos mineiros. Em parte das fazendas com cultivo e transformação da cana, a fabricação dos derivados estava restrita a poucos meses; em outro extremo, os engenhos com safra longa funcionavam durante todo o ano. Todavia, a safra do engenho médio girava em torno de seis meses (Ibidem, p.58-76). Com relação ao grau de mobilização da força de trabalho escrava, os dados disponíveis são objetivos. Em parte significativa das listas nominativas que compóem o Censo de 1831-32 foi anexada Relação de Fábricas. ${ }^{5} \mathrm{O}$ cruzamento da informação do número de escravos empregados em 289 engenhos de cana, relacionados nas Relações de Fábricas, com os respectivos plantéis de seus proprietários, arrolados no corpo da respectiva lista nominativa, permitiu conhecer a parcela da força de trabalho cativa efetivamente empregada na fabricação de derivados da cana. O resultado desta justaposição de dados indicou elevada participação média dos escravos nas atividades agroaçucareiras. Na safra, quase $90 \%$ dos cativos eram alocados na elaboração de aguardente, rapadura e açúcar. A avaliação dos dados segmentados segundo o percentual de

4 O Censo de 1831/32, organizado sob a forma de listas nominativas de habitantes, é o mais extenso e circunstanciado levantamento populacional do período provincial mineiro. As unidades espaciais de informação do censo eram os distritos de paz, divididos em fogos. Foram relacionados para cada indivíduo o prenome, a condição social, a cor/origem e a idade. Sobrenome, estado conjugal, ocupação, nacionalidade e relaçóes de parentesco ou subordinação socioeconômica foram informados para parcela da população. A representatividade e cobertura das listas remanescentes de 1831/32 são bastante satisfatórias, compreendem aproximadamente $55 \%$ da população e distritos então existentes em Minas Gerais (PAIVA, 1996, p. 54-75).

5 Das 230 listas nominativas de 1831-32, 109 (47\%) foram acompanhadas das Relações de Fábricas. As informações solicitadas eram o nome do proprietário, sua nacionalidade, a natureza do estabelecimento e o número de trabalhadores livres e escravos empregados. Entre todas as atividades integrantes do universo de fábricas, a transformação da cana-de-açúcar era de longe a mais incidente. Dos 109 documentos com Relaçôes de Fábricas, em 78 (72\%) foram relacionados engenhos de cana. 
comprometimento dos escravos com a fabricação de derivados da cana revela níveis diferenciados, inclusive com ponderável número de casos em que provavelmente se recorria ao aluguel de cativos. Os variados níveis de alocação dos escravos nas atividades do engenho sugerem diversas formas de inserção da produção no mercado, de produção de autoconsumo e eventual geração de excedentes à especialização com regular produção para o mercado.

\section{TABELA 4 - PARTICIPAÇÃO DA FORÇA DE TRABALHO ESCRAVA NA FABRICAÇÃO DE DERIVADOS DA CANA, CENSO DE 1831-1832 E RELAÇOOES DE FÁBRICAS, MINAS GERAIS, 1831-1832}

\begin{tabular}{lrrc}
\hline $\begin{array}{l}\text { Percentual dos escravos empregados na } \\
\text { fabricação de derivados da cana }\end{array}$ & \multicolumn{2}{c}{ Engenhos } & $\begin{array}{c}\text { Percentual médio de escravos } \\
\text { empregados na fabricação de } \\
\text { derivados da cana }\end{array}$ \\
\cline { 2 - 3 } 10 a 49 & 31 & 10,7 & 34,5 \\
50 a 99 & 139 & 48,1 & 73,1 \\
100 & 83 & 28,7 & 100,0 \\
+ de 100 & 36 & 12,5 & 167,2 \\
& 289 & 100,0 & 87,3 \\
\hline
\end{tabular}

Fonte: Arquivo Público Mineiro: SPPP1/10 e MP, diversas caixas.

Em síntese, para efeito da construção da estimativa do número de escravos empregados no setor canavieiro, considera-se que a safra da cana mobilizava, direta ou indiretamente, todos os cativos das unidades produtivas com atividades agroaçucareiras. Ainda que as demais atividades exigissem a realização de outras tarefas, posto que a diversificação era importante traço da identidade destas unidades produtivas, pelo menos parte do tempo de trabalho dos escravos destinava-se às funções pertinentes à elaboração de aguardente, rapadura e açúcar.

O exame da tabela e mapa seguintes, que apresentam a estimativa regionalizada do número de escravos empregados no setor canavieiro de Minas Gerais, evidencia a assimetria entre a distribuição relativa dos cativos e a distribuição relativa dos engenhos, decorrência dos contrastes entre as médias regionais de escravos por engenho (Ibidem, p.422). Dessa forma, algumas regiões que apresentavam elevado percentual de engenhos perfaziam número relativo de escravos bem menos significativo, ou o contrário, algumas regiões com percentual pouco expressivo de engenhos e significativa participação relativa de cativos.

A estimativa do número de escravos empregados em atividades agroaçucareiras revela que, na década de 1830, a elaboração de derivados da cana em Minas Gerais mobilizava mais de um terço dos cativos do maior plantel escravista do Brasil (MARTINS, 1982). Conquanto atividade sazonal, a fabricação de aguardente, rapadura e açúcar 
requeria mais de 85 mil escravos do universo de aproximadamente 238 mil cativos da província (PAIVA; GODOY, 2001). Reafirma-se a forte conexão entre a produção de derivados da cana e trabalho escravo. Voltadas para o mercado interno e inseridas em expressiva parcela das diversificadas fazendas mineiras, as atividades agroaçucareiras respondiam em larga medida pelo dinamismo da economia escravista de Minas.

TABELA 5 - ESTIMATIVA REGIONAL DO NÚMERO DE ESCRAVOS EMPREGADOS NOS ENGENHOS, MINAS GERAIS, 1836

\begin{tabular}{lrrrr}
\hline Regiões & $\begin{array}{c}\text { Engenhos de } \\
\text { cana }\end{array}$ & $\begin{array}{c}\text { Número médio de escravos } \\
\text { por engenho (GODOY, } \\
\text { 2004, p. 422) }\end{array}$ & $\begin{array}{c}\text { Número de escravos } \\
\text { empregados nos engenhos } \\
\text { de cana }\end{array}$ \\
\cline { 3 - 4 } & & & No & $\%$ \\
\hline Vale do Alto-Médio Rio São Francisco & 108 & 20,7 & 2.236 & 2,6 \\
Sertão & 64 & 20,7 & 1.325 & 1,6 \\
Minas Novas & 339 & 6,8 & 2.305 & 2,7 \\
Triângulo & 67 & 7,5 & 503 & 0,6 \\
Araxá & 76 & 10,7 & 813 & 1,0 \\
Paracatu & 24 & 10,7 & 257 & 0,3 \\
Sertão do Alto São Francisco & 71 & 17,8 & 1.264 & 1,5 \\
Sertão do Rio Doce & 2 & 14,5 & 29 & 0,0 \\
Diamantina & 36 & 14,6 & 526 & 0,6 \\
Vale do Médio-Baixo Rio das Velhas & 314 & 22,2 & 6.971 & 8,2 \\
Intermediária de Pitangui-Tamanduá & 595 & 20,1 & 11.960 & 14,1 \\
Mineradora Central Oeste & 1.062 & 25,2 & 26.762 & 31,5 \\
Mineradora Central Leste & 500 & 14,5 & 7.250 & 8,5 \\
Mata & 239 & 26,0 & 6.214 & 7,3 \\
Sudeste & 185 & 39,3 & 7.271 & 8,5 \\
Sul Central & 347 & 19,8 & 6.871 & 8,1 \\
Sudoeste & 121 & 20,2 & 2.444 & 2,9 \\
Minas Gerais & 4.150 & 20,5 & 85.075 & 100,0 \\
\hline & & & & \\
\hline
\end{tabular}

Fonte: Arquivo Público Mineiro, MP, SPPP $1 / 10$ e SPPP $1 / 6$, diversas caixas. ${ }^{*} \mathrm{~A}$ inexistência de dados para três regióes foi resolvida com a adoção de média de regiões vizinhas que guardavam algumas características semelhantes (ver GODOY, 1996). Para Paracatu, foi utilizada a média de Araxá; para o Sertão do Rio Doce, a da Mineradora Central Leste; para o Vale do Alto-Médio São Francisco, a do Sertão. 


\section{MAPA 2 - ESTIMATIVA REGIONAL DO NÚMERO DE ESCRAVOS EMPREGADOS NOS ENGENHOS DE CANA - MINAS GERAIS - $B R A S I L-1836$}

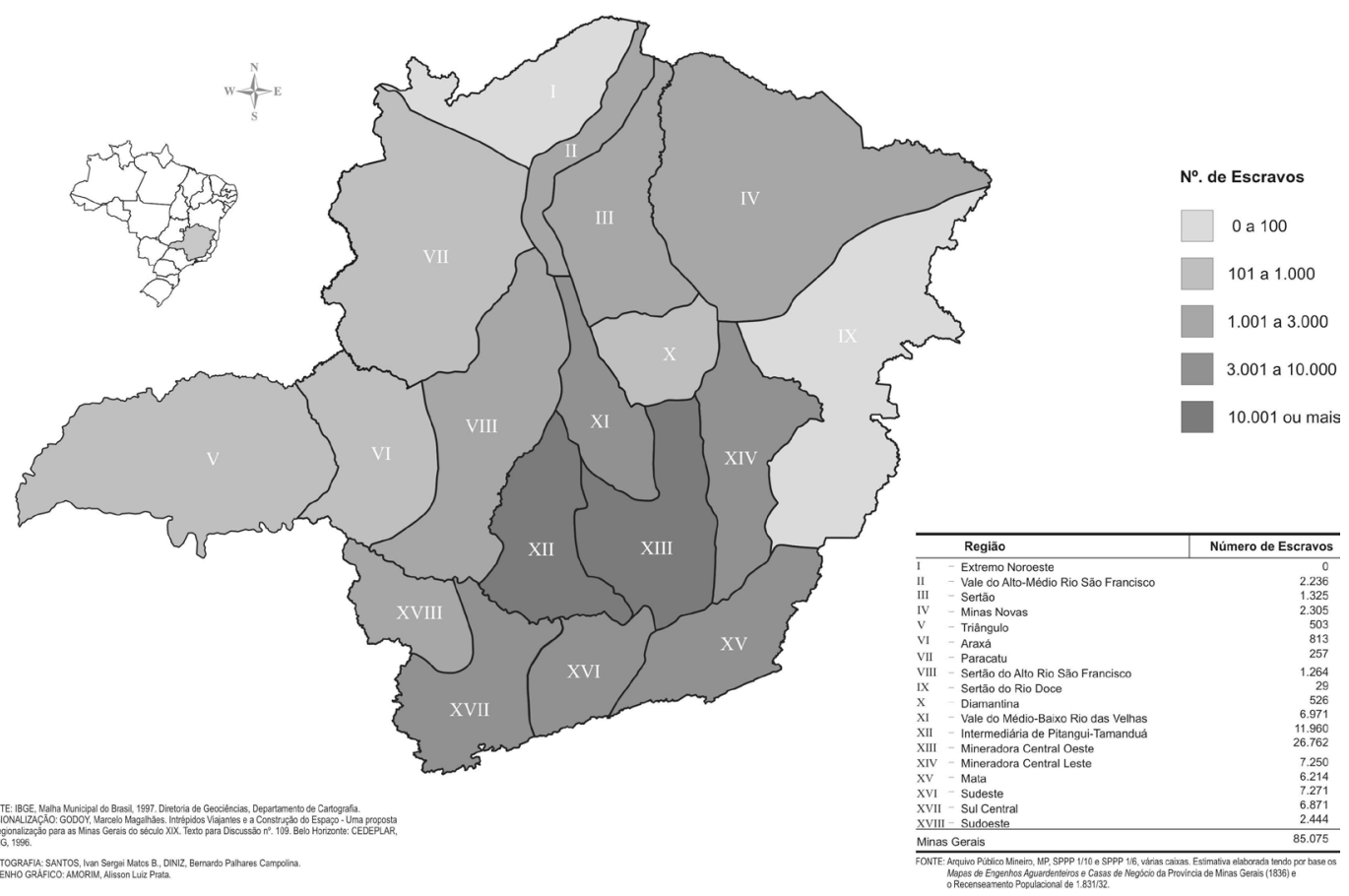

Peter Eisenberg apresenta duas médias de escravos por engenho: para o período 1840-1845, foi apurada média de 55 cativos para 331 engenhos; no período 18501855, a média, para 532 engenhos, era de 20 escravos (EISENBERG, 1977, p. 169). Considerados os 925 engenhos estimados para 1844 e adotada a maior média, resulta contingente de 50.875 cativos no setor canavieiro de Pernambuco. ${ }^{6}$ Oito anos antes, o número de escravos empregados em Minas era $67 \%$ maior. Josué Subrinho apresenta média de 55,4 escravos por engenho para o ano de 1851 e 21,1 para 18571858 (SUBRINHO, 2000, p. 95-98). Aplicada a maior média para os 445 engenhos de 1838, o plantel de Sergipe seria de 24.653 escravos. Na ausência de dados para Alagoas, adota-se o mesmo tamanho médio de Sergipe. Assim, em 1849, os 316 engenhos de Alagoas empregariam 17.506 escravos. A escravaria das duas pequenas províncias somava 42.159 cativos. Era 102\% maior o contingente de escravos no setor canavieiro de Minas Gerais. Referentes ao Recôncavo Baiano, os dados de 1816-1817 estudados por Stuart Schwartz compreenderam 165 engenhos, que re-

6 É provável que Eisenberg tenha chegado a estas médias considerando exclusivamente os engenhos do Agreste e Zona da Mata, faltando-lhe dados para as unidades do Sertão. Portanto, a adoção de média geral obtida com base nos grandes plantéis dos engenhos economicamente mais dinâmicos tende à superestimação do número de escravos do setor canavieiro da província. 
presentavam "mais de dois terços dos 240 engenhos do Recôncavo e de quase a metade dos 340 da capitania”. Schwartz calculou que o número médio de escravos por engenho era de 65,5 (SCHWARTZ, 1988, p. 356-368). Considerada esta média para todo o espaço canavieiro baiano, em 1833, os 603 engenhos da província empregariam 39.497 escravos. $^{7}$ Os engenhos de Minas ocupavam força de trabalho escrava $115 \%$ maior. Para o Rio de Janeiro, foram adotados os dados de Iraci del Nero da Costa, baseados na Relação do Marquês de Lavradio de 1788. A posse média dos engenhos produtores de açúcar e aguardente era de 36 escravos e a das engenhocas que elaboravam aguardente era de 10,8 cativos (COSTA, 1988, p. 111-113). Adotada a posse média de 36 escravos por engenho de 1778 para os 788 engenhos computados para 1852, obteve-se contingente de 28.368 cativos. Em Minas, o número de escravos empregados no setor canavieiro era 200\% maior. Em 1834, nos engenhos de Campinas, a mais importante área canavieira de São Paulo, trabalhavam em média 37 escravos (PETRONE, 1968, p. 26-53 e 113). Considerada esta média para os 821 engenhos existentes em 1836, resulta contingente de 30.377 escravos no setor canavieiro paulista. ${ }^{8}$ Os engenhos mineiros ocupavam plantel de cativos $180 \%$ maior.

Mesmo desconsiderada a provável superestimação dos dados de Pernambuco, Bahia e São Paulo, assim como o período distinto dos dados para o Rio de Janeiro, Alagoas e Pernambuco, o plantel de Minas Gerais era equivalente a $45 \%$ da soma dos plantéis das demais províncias canavieiras. Diante do tamanho da força de trabalho escrava das atividades agroaçucareiras de Minas, é provável que em nenhum outro espaço canavieiro, em qualquer período da história do Brasil que se considere, tenha sido empregado contingente de cativos da mesma magnitude.

7 Como no caso de Pernambuco, a adoção de média geral tende a acentuada superestimação do número de escravos empregados no setor canavieiro de toda a província. O Recôncavo era a regiáo economicamente mais dinâmica e escravista da Bahia. Os engenhos do Agreste e, especialmente, do Sertão seguramente apresentavam estruturas da posse de escravos muito distintas.

8 A adoção desta média superestima o plantel escravista do setor canavieiro paulista. As zonas produtoras do litoral, Vale do Paraíba e municípios do planalto localizados fora do Quadrilátero do Açúcar possuíam média de escravos bem mais modesta. 


\section{TABELA 6 - NÚMERO DE ESCRAVOS EMPREGADOS NOS ENGENHOS DOS PRINCIPAIS ESPAÇOS CANAVIEIROS DO BRASIL, 1836-1852}

\begin{tabular}{lcc}
\hline Espaço canavieiro & Ano & Número de escravos \\
\hline Minas Gerais & 1836 & 85.075 \\
Pernambuco & 1844 & 50.875 \\
Alagoas & 1849 & 17.506 \\
Sergipe & 1838 & 24.653 \\
Bahia & 1833 & 39.497 \\
Rio de janeiro & 1852 & 28.368 \\
São Paulo & 1836 & 30.377 \\
\hline
\end{tabular}

Fonte: Pernambuco (EISENBERG, 1977, p. 169); Alagoas e Sergipe (SUBRINHO, 2000, p. 95-98); Bahia (SCHWARTZ, 1988, p. 356-368); Rio de Janeiro (COSTA,1988, p. 111-113); São Paulo (PETRONE, 1968, p. 26-53 e 113).

\section{ESTIMATIVA DA PRODUÇÃO DE AÇÚCAR, RAPADURA E AGUARDENTE}

A aparente inexistência de dados que possibilitem conhecer o tamanho da produção da agropecuária e da transformação rural talvez configure em um dos principais óbices ao refinamento da compreensão do caráter da economia mineira provincial. Demonstrado o dinamismo da organização econômica de Minas, especialmente expresso no vigor da escravidão, e reconhecida a importância do mercado interno provincial, principalmente por sua magnitude, resta conhecer alguns aspectos essenciais da produção de subsistência de gêneros da agropecuária (MARTINS, 1982; SLENES, 1985; PAIVA, 1996). O estágio presente do conhecimento das fontes históricas para o estudo do mercado interno da província apresenta as seguintes características: 1. predomínio de esparsas e incompletas informações permite a aferição parcial e indireta do tamanho da produção e da direção dos fluxos locais e regionais de gêneros de abastecimento; 2. dados para alguns anos e para parte dos postos fiscais são insuficientes para a avaliação do comportamento no tempo das exportações e importações e com cobertura que alcance a totalidade do comércio externo; 3. exíguas e subjetivas impressões conformam frágil imagem do consumo interno. Estas restrições documentais permeiam o estudo da produção e comercialização de derivados da cana de Minas Gerais: são descontínuos e lacunosos os raros registros nominais dos dízimos; os recenseamentos nominais da população não documentaram a produção dos domicílios; da tributação incidente sobre a circulação interna remanesceram dados locais isolados e incompletos; os inquéritos provinciais raramente forneceram informes objetivos sobre a produção e comércio locais; as perspectivas 
de estudo de documentação contábil do comércio estabelecido e de longa distância, combinadas com a exploração dos lançamentos de ativos e passivos registrados em inventários, deverão consolidar redes de vinculação comercial, sem permitir, contudo, a mensuração do tamanho e destino da produção agrícola interna.

Na Rellação das Fabricas de Santo Antônio do Calambau (GODOY, 2004, p.541), distrito do município de Mariana, foram recolhidos dados fundamentais à proposição de estimativa do tamanho e distribuição espacial da produção de derivados da cana de Minas Gerais. Às informações que deveriam compor a Rellação das Fabricas, o juiz de paz acrescentou dados relativos à safra agrícola distrital. Foi discriminado o tamanho da produção de derivados da cana, fumo e café, provavelmente gêneros exportados pelo distrito. Estes dados ganham importância pela similitude entre as características do microcosmo dos engenhos de Calambau em relação ao conjunto do setor canavieiro provincial (Ibidem, p. 414-427). O exame de vários aspectos da estrutura da posse de escravos, da força motriz dos engenhos, de características dos engenheiros, de elementos da organização econômica das fazendas e da direção da produção evidenciou que os dados de Calambau eram representativos do setor canavieiro provincial.

No Censo de 1831-1832, foram arrolados 1.406 habitantes no distrito de Calambau. A composição da população segundo a condição social apresentava diferença não muito pronunciada em relação à do conjunto da província: os escravos respondiam por $38,3 \%$ da população de Calambau; para Minas Gerais, alcançavam $33,1 \%$. Cotejo entre o número de habitantes e o número de engenhos revela que a Mineradora Central Oeste, região em que estava Calambau, não pertencia ao grupo de regiões que provavelmente apresentavam algum grau de especialização no cultivo e transformação da cana e eram exportadoras líquidas de derivados, tampouco pertencia ao grupo de regióes com probabilidade de serem importadoras líquidas de subprodutos da cana em função de organização econômica especializada em outras atividades e/ou com a presença de fatores naturais adversos ao desenvolvimento da gramínea (Ibidem, p. 414-427). Assim, constata-se que a Mineradora Central Oeste pertencia a grupo de regiões cujas características de seus setores canavieiros estavam próximos da média dos atributos gerais do conjunto da economia canavieira provincial. Portanto, a localização é fator favorável à demonstração da representatividade do setor canavieiro do distrito de Calambau.

Quase 40\% dos equipamentos de moagem da região Mineradora Central Oeste eram movimentados por energia hidráulica, ao passo que apenas $22 \%$ dos engenhos de Minas eram acionados por esta força motriz. Ainda que localizado nesta região, Calambau apresentava percentual de engenhos d’água mais próximo do provincial $(28,6 \%)$. Também neste aspecto, Calambau afirma-se como representativo do con- 
junto do setor canavieiro (Ibidem, p.543). As características sociodemográficas (sexo, cor ou origem étnica, idade e estado conjugal) dos engenheiros de Calambau coincidiam ou pouco diferiam daquelas válidas para o conjunto dos engenheiros de Minas Gerais. (Ibidem, p. 544). A estrutura da posse de escravos de Calambau guardava grandes semelhanças com a dos engenheiros em geral e acentuadas divergências com relação à provincial. Enquanto o escravismo provincial caracterizava-se pela ampla predominância das pequenas e médias posses, que respondiam por quase $85 \%$ dos plantéis, as unidades com engenho de cana distinguiam-se pela pronunciada participação das grandes posses, que perfaziam $62 \%$ dos plantéis de Calambau e $66,7 \%$ de Minas Gerais. As médias de 21,4 escravos por plantel nos fogos com engenho e 17,9 para Calambau superavam largamente a média provincial de 6,6 escravos. $\mathrm{Na}$ província, não foram arrolados escravos em $68 \%$ dos fogos, o percentual para os fogos com engenho não alcançava $5 \%$ e em Calambau inexistiam engenheiros não escravistas (Ibidem, p.545). Os dados de Calambau também eram semelhantes aos dos engenhos em geral se considerada a participação relativa dos escravos nas fábricas de cana. No distrito de Mariana, $83,2 \%$ dos escravos eram empregados na fabricação dos derivados; para os 289 engenhos examinados, o percentual correspondente era de 87,3 .

O resultado do cotejo entre as características do microcosmo canavieiro de Calambau e os atributos do setor canavieiro provincial é a constatação da representatividade dos dados arrolados pelo juiz de paz distrital. Assim sendo, na seqüência estima-se a produção regionalizada de derivados da cana de Minas Gerais com base nos dados de Calambau e na estimativa do número de escravos empregados em atividades agroaçucareiras. Na tabela seguinte são apresentadas as produções médias de açúcar, rapadura e aguardente por engenho e por escravo. Dividiu-se a produção distrital de cada derivado pelo conjunto de unidades com cultivo e transformação da cana e pelo número total de cativos empregados nos engenhos de Calambau. Em consonância com a histórica composição da produção mineira de derivados, verifica-se a maior magnitude da produção de rapadura e aguardente e a posição menos expressiva da produção de açúcar. 


\section{TABELA 7 - PRODUÇÃO MÉDIA POR ENGENHO E POR ESCRAVO, SANTO ANTÔNIO DO CALAMBAU, MINAS GERAIS, 1831}

\begin{tabular}{lccccccc}
\hline \multirow{2}{*}{$\begin{array}{l}\text { Unidade de } \\
\text { produção }\end{array}$} & \multicolumn{2}{c}{ Açúcar } & \multicolumn{3}{c}{ Rapadura } & \multicolumn{2}{c}{ Aguardente } \\
\cline { 2 - 8 } & Arrobas & Quilos & Cargas & Unidades & Quilos & Barris & Litros \\
\hline Engenho & 95,2 & 1.429 & 34,3 & 2.194 & 4.388 & 183,8 & 3.860 \\
Escravo & 6,4 & 95,8 & 2,3 & 147,2 & 294,4 & 12,3 & 259,0 \\
\hline
\end{tabular}

Fonte: Arquivo Público Mineiro: SPPP 1/10, caixa 18, doc. 3. Arroba $=15$ quilos; Carga $=64$ unidades; Barril $=21$ litros; Rapadura $=2$ quilos .

Com o objetivo de ampliar a demonstração da representatividade dos dados de Calambau, utilizados na elaboração da estimativa da produção provincial de derivados da cana, estabeleceu-se o cotejo da produção média de derivados por engenho do distrito marianense com dados da mesma natureza para três momentos da evolução das atividades agroaçucareiras tradicionais de Minas Gerais no século 20. Em 1920, 21.158 engenhos elaboravam 122.980 toneladas de açúcar/rapadura (5.812 quilos por engenho) e 3.022 engenhos produziam 35.098 mil litros de aguardente (11.614 litros por engenho). Comparada com Calambau, a produção média de açúcar/rapadura em 1920 era praticamente a mesma e a de aguardente $201 \%$ maior (Carteira Estatistica de Minas Geraes, 1929, p. 299). Em 1960, 1.233 engenhos fabricavam 3.917 toneladas de açúcar (3.177 quilos por engenho), 32.037 engenhos elaboravam 74.488 toneladas de rapadura (2.325 quilos por engenho) e 2.108 engenhos produziam 23.140 mil litros de aguardente (10.977 litros por engenho). Comparada com Calambau, a produção média de açúcar em 1960 era $122 \%$ maior, a de rapadura 47\% menor, a de açúcar/rapadura 59\% menor e a de aguardente 184\% maior (IBGE, Censo Agrícola, 1960). Em 1995, 343 engenhos elaboravam 675 toneladas de açúcar (1.968 quilos por engenho), 14.817 engenhos fabricavam 17.004 toneladas de rapadura (1.147 quilos por engenho) e 8.466 engenhos produziam 44.665 mil litros de aguardente (5.275 litros por engenho). Comparada com Calambau, a produção média de açúcar em 1995 era 38\% maior, a de rapadura 74\% menor, a de açúcar/rapadura 80\% menor e a de aguardente $37 \%$ maior (IBGE, Censo Agropecuário, 1995).

Entre 1831 e 1920, a média da produção de açúcares de engenho manteve-se a mesma, passando de 5.817 quilos para 5.812 quilos. Enquanto a produção mineira era majoritariamente artesanal (em 1920 as usinas fabricavam apenas $6,1 \%$ do açúcar do Estado) e respondia pelo atendimento quase que exclusivo do mercado interno de Minas, prevaleceu padrão histórico de crescimento do setor sempre em estreita correlação com variáveis geográficas e demográficas (Ibidem, p. 22-111). A grande semelhança entre a média de produção de açúcar por engenho de 1831 e a média de 1920 fortalece a pertinência em se considerar o microcosmo de Calambau 
como representativo das atividades agroaçucareiras da província de Minas Gerais. Consoante a evolução da participação relativa da produção industrial no cômputo geral da produção de açúcar mineira, entre as décadas de 1920 e 1960 avançou a modernização tecnológica das atividades agroaçucareiras, com as usinas respondendo em 1960 por 56\% da produção de açúcar (Ibidem, p. 82-111). Debaixo da concorrência interna do congênere industrial e externa de crescentes importações de açúcar de outros Estados, desestruturou-se o referido padrão de desenvolvimento da produção tradicional. Destas transformaçôes decorreu a significativa queda na produção média de açúcar por engenho entre 1920 e 1960, de 5.812 quilos para 2.357 quilos. A produção média de açúcar por engenho de 1995, 1.166 quilos, ou $50 \%$ inferior à média de 1960, evidencia estágio avançado de perda de dinamismo econômico das atividades agroaçucareiras tradicionais.

Histórico problema fiscal dificulta a compreensão da evolução da produção média de aguardente por engenho (Ibidem, p.154-184). Apenas elevada incidência de unidades produtivas clandestinas pode explicar o pequeno crescimento do número de engenhos que fabricavam o destilado, de 1836 (2.480) para 1920 (3.022), comparado com a pronunciada expansão dos engenhos que produziam açúcar e rapadura, de 2.480 (1836) para 21.158 (1920). Em 1960, o número de engenhos aguardenteiros (2.108) não apenas decresceu se comparado com 1920, como se apresentava $15 \%$ menor do que o de 1836. Diante desse quadro, é razoável supor que a histórica postura dos produtores de aguardente em se esquivarem dos recenseadores, confundidos com exatores ou a eles associados (Ibidem, p.154-184), foi muito mais eficiente para os proprietários de engenhos menores e com pequena produção anual e, por conseqüência, elevou substantivamente a participação relativa dos engenhos maiores e com grande produção anual, afetando sobremaneira a produção média de aguardente por engenho em 1920 e 1960. Os dados de 1995 se coadunam a esta suposição, visto que o crescimento acentuado do número de engenhos aguardenteiros, mais de $300 \%$ em relação a 1960, resultou em produção média por engenho sobremaneira menor (5.275 litros) e não muito distante da encontrada para 1836 (3.860 litros). Ao contrário da produção de açúcares de engenho, com tendência declinante desde meados do século 20, a produção de aguardente encontrava-se em expansão no final do Novecentos (Ibidem, p. 82-111).

O desejável passo seguinte na construção da estimativa da produção provincial de derivados da cana seria conhecer a produção média regional dos trabalhadores dos engenhos. Para a primeira metade do século 19, as evidências disponíveis para outras regiões de Minas estão longe de alcançar a objetividade e representatividade dos dados de Calambau. São, em geral, impressões subjetivas de viajantes estrangeiros, na maior parte das vezes fundadas na observação de unidade produtiva isolada ou fruto de especulação, sem nenhuma explicitação das fontes que permitam a necessá- 
ria avaliação de consistência e representatividade. ${ }^{9}$ Diante destas limitações, optou-se por aplicar a produção média de Calambau a todas as regiões. Em Minas, variáveis fundamentais à determinação da produção média dos trabalhadores em engenhos eram regionalmente semelhantes, como os equipamentos e processos técnicos das etapas agrícola e industrial, o tamanho das safras e a formação profissional dos trabalhadores. Os desníveis técnicos e diferenças quanto à extensão da safra eram fenômenos de natureza local, muito mais resultado da combinação de específica gestão empresarial, particular disponibilidade de recursos econômicos e favoráveis condições de mercado do que de configurações regionais distintas.

Na tabela e mapa seguintes são apresentadas as estimativas regionais da produção e produção per capita de derivados da cana. A produção regional foi calculada com a multiplicação do número de escravos empregados nos engenhos (Tabela 5) pelas produções médias de Calambau (Tabela 7). A produção per capita resultou da divisão da produção das regiões pelas respectivas populações regionais (Ibidem, p. 245).

Com a mensuração da produção per capita objetiva-se o robustecimento de evidências de distintas capacidades regionais no atendimento das necessidades de consumo de derivados da cana e, por decorrência, a segmentação das regiões em: 1. auto-suficientes; 2. dependentes de suprimentos externos; 3 . geradoras de excedentes exportáveis. As divergências nos valores referentes à produção per capita confirmam desníveis no tocante à participação relativa da produção canavieira nos quadros das economias regionais (Ibidem, p. 414-427). Os maiores valores de produção per capita, aqueles que estavam acima da produção per capita provincial, provavelmente indicam aquelas regiões cuja produção excedia as necessidades de consumo de derivados da cana de suas populações. Ao contrário, os menores valores de produção per capita, aqueles que estavam abaixo da produção per capita provincial, devem assinalar aquelas regiões incapazes de atender as necessidades de consumo de suas populações.

9 Estas restrições encontradas para Minas são válidas também para espaços regionais historicamente identificados com o cultivo e transformação da cana. Todos os dados de produção para Pernambuco, apresentados por Eisenberg, para a primeira metade do século 19, foram recolhidos em relatos de viajantes estrangeiros (EISENBERG, 1977, p. 78). Da mesma forma, Petrone destaca as impressões de Saint-Hilaire sobre a produção dos engenhos paulistas na primeira metade do Oitocentos (PETRONE, 1968, p. 111-114). 


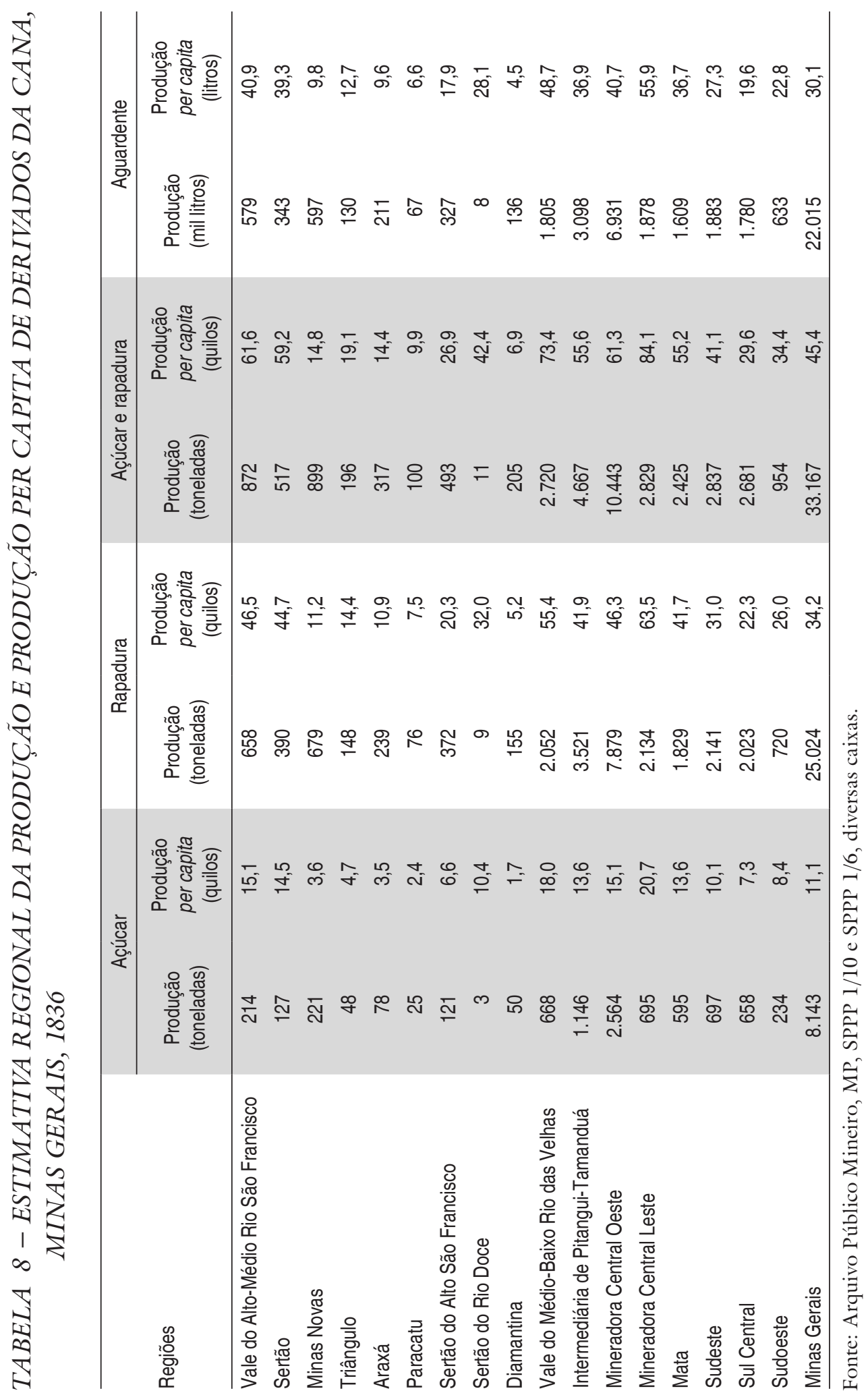




\section{MAPA 3 - ESTIMATIVA REGIONAL DA PRODUÇÃO PER CAPITA DE DERIVADOS DE CANA - MINAS GERAIS - BRASIL - 1836}

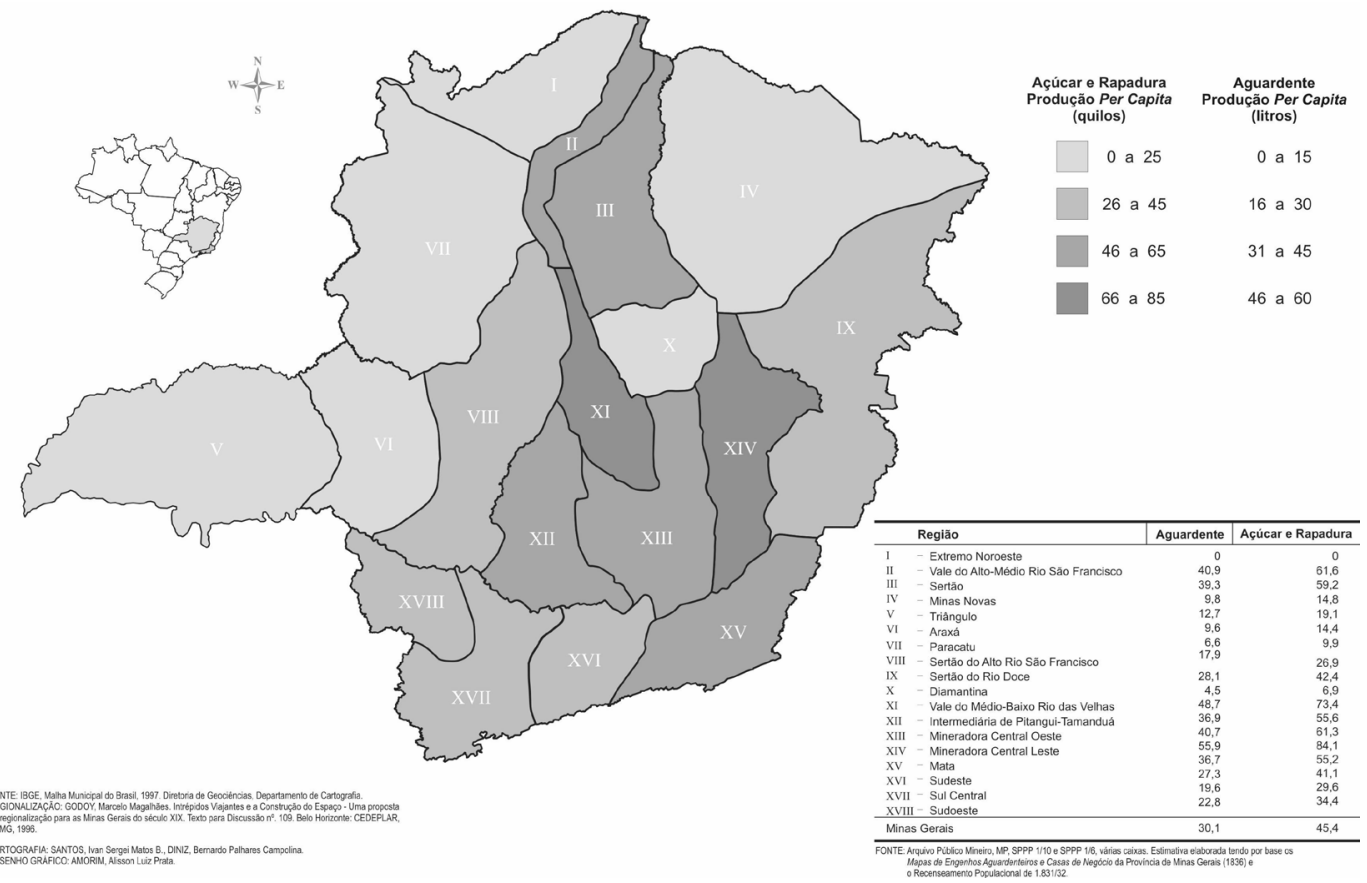

Em 1836, a quantidade de açúcar produzida em Minas Gerais era equivalente à de São Paulo, bem superior à de Alagoas e Sergipe e pequena ante a de Pernambuco, Bahia e Rio de Janeiro. Minas fabricava algo em torno de 10\% das exportações brasileiras de açúcar. A rapadura não tinha expressão na pauta produtiva dos engenhos do litoral do Nordeste e das províncias do Rio de Janeiro e São Paulo. A fabricação de açúcar na forma de tijolos somente alcançava significado no Sertão nordestino. Ainda assim, em volume insuficiente para o provimento das populações sertanejas, dadas as grandes quantidades de rapadura exportadas, de Minas Gerais para o interior da Bahia e Pernambuco. ${ }^{10}$ Considerado o açúcar em todas as suas formas, a província de Minas Gerais ocupava a posição de maior produtora do Brasil na década de 1830. As 33.167 toneladas de açúcar purgado e rapaduras superavam largamente a produção de Alagoas, Sergipe e São Paulo somadas, eram o dobro da produção do Rio de Janeiro e ultrapassavam em alguns milhares de toneladas a produção de Pernambuco e da Bahia.

10 Minas exportava para o Sertão nordestino, entre os anos de 1816-1822, média anual de 193 toneladas de rapadura, quase $200 \%$ a mais do que as 66 toneladas exportadas anualmente pela Bahia nas décadas de 1840 e 1850 (GODOY, 2004, p. 154-185). 
Os engenhos do litoral nordestino, do norte fluminense e do Planalto Paulista eram especializados na fabricação de açúcar. A tendência era da produção de aguardente ter pequena importância ante a de açúcar. Somente em determinadas áreas, como o litoral sul do Rio de Janeiro e o litoral norte de São Paulo, a aguardente ocupava posição de destaque na pauta produtiva dos engenhos. Em Minas Gerais, ao contrário, a fabricação de aguardente realizava-se em número de engenhos igual ao em que se fabricavam açúcar e/ou rapadura, e em aproximadamente $20 \%$ das unidades elaborava-se ao mesmo tempo o destilado e açúcar e/ou rapadura (Tabela 1). Além disso, em Minas o volume de aguardente produzido rivalizava com o de açúcar/rapadura. Desses fatos resultava a grande distância entre a quantidade de aguardente produzida em Minas e a dos demais espaços canavieiros. 


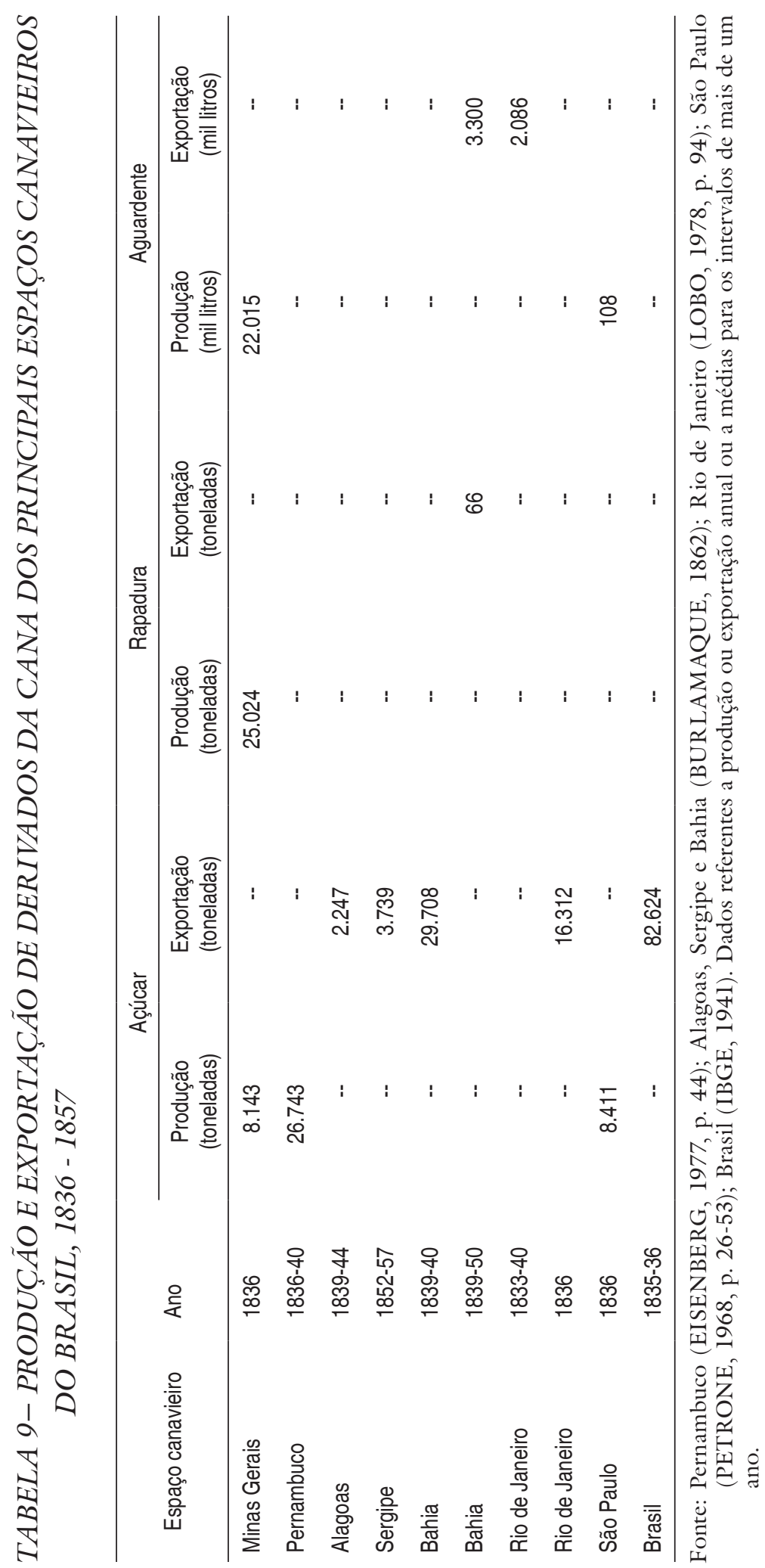




\section{COMÉRCIO INTERNO E EXTERNO DE DERIVADOS DA CANA}

A auto-suficiência de Minas Gerais no provimento de açúcares e destilados da cana não excluía a existência de ponderáveis fluxos interprovinciais de importação e exportação de derivados da cana. Conquanto em termos absolutos as quantidades movimentadas no comércio externo fossem significativas, confrontadas com a estimativa da produção interna, portanto em termos relativos, não alcançavam expressão relevante. Na primeira metade do século 19, as remessas de açúcar para o exterior de Minas nunca alcançaram 2\% da produção de 1836 e as de rapadura jamais chegaram a 1\%. Também eram inexpressivos os fluxos interprovinciais de importação de açúcar, rapadura e aguardente. Apenas no sul de Minas Gerais eram regulares as entradas de derivados da cana. Os dados disponíveis referem-se às importações realizadas através de recebedoria localizada próximo de Campinas, o mais importante município açucareiro paulista. Os registros cobrem os anos de 1824 a 1832. A média anual importada não alcança, para nenhum dos derivados, sequer a $0,1 \%$ da produção mineira de 1836 (Ibidem, p. 552).

Com base em documentação fiscal, foram investigados dados referentes às importações de aguardente realizadas pela cidade de Ouro Preto na segunda metade do século 19 (Ibidem, p. 154-185). Os dados da entrada de aguardente pela Recebedoria do Taquaral permitem aproximação do consumo per capita de Ouro Preto. A média mensal de 17.241 litros de aguardente dividida por 13.567 ouro-pretanos (SILVA, 1997) projeta consumo per capita anual de 15,3 litros. Dado que a cobrança do oneroso tributo inviabilizava a possibilidade de a capital provincial funcionar como entreposto de reexportação, pode-se afirmar que a aguardente destinava-se ao consumo local. Além disso, esta projeção de consumo fundamenta-se em apenas um dos quatro postos fiscais em que se tributava a entrada do destilado na capital e não considera o certamente elevado contrabando. Dessa forma, é razoável supor consumo per capita muito mais elevado. Se a produção mineira voltava-se quase exclusivamente para o consumo interno da própria província, o consumo de aguardente que a estimativa da produção per capita de 1836 sinaliza é compatível com o sugerido pelos dados do Taquaral (GODOY, 2004, p. 154-185).

Nos Mapas de 1836 remanescentes foram arroladas 5.049 casas de negócio para 297 distritos. A partir desses dados, foram estimados 6.596 estabelecimentos para os 419 distritos então existentes. Nos Mapas de 1836, enquanto os espíritos importados eram vendidos em 12,9\% das casas de negócio, a aguardente de Minas estava presente em $69,7 \%$. A ampla disseminação espacial do comércio estabelecido de aguardente coadunava-se com a ubíqua fabricação do destilado e sustentava difundido consumo (Ibidem, p. 319-325). 
Como avançado, as evidências disponíveis autorizam considerar que a produção mineira de derivados da cana destinava-se quase exclusivamente ao consumo interno da própria província. Assim, pode-se tomar a produção per capita como boa aproximação do consumo per capita e, como desdobramento, estabelecer cotejo com dados de consumo para outros períodos. Na década de 1920, Minas Gerais apresentava consumo per capita de açúcar acima da média nacional. ${ }^{11}$ Em 1940, o consumo per capita de açúcar "de todos os tipos" de Minas era de 26,1 quilos; o consumo de "tipos de usina" respondia por 8,8 quilos e o de "tipos de engenho" perfazia 17,3 quilos (Anuário Açucareiro, 1942, p. 147-148). Em avaliação retrospectiva do Diagnóstico da Economia Mineira, o desenvolvimento do setor canavieiro de Minas nos primeiros decênios do século 20 esteve fortemente condicionado pela persistência de problemas estruturais que, ao final da década de 1930, impediram que o Estado acelerasse a expansão da produção industrial de açúcar. ${ }^{12}$ No início da década de 1960, segundo dados do IAA, o consumo per capita de "açúcar tipo usina" de Minas Gerais (29,3 $\mathrm{kg}$ ) era bem menor do que dos Estados do Rio de Janeiro e São Paulo. ${ }^{13}$ Os dados de "consumo aparente per capita" das décadas de 1950 e 1960, publicados pelo IAA, já não incluíam os "tipos de engenho". Entretanto, o Censo Agrícola de 1960, do IBGE, contemplou a produção de açúcar em estabelecimentos rurais. Considerada a provável inexpressividade das exportações mineiras de açúcares não-industriais, pode-se afirmar que as 95.078 toneladas de açúcar e rapadura produzidas em engenhos representavam consumo adicional de 8,8 quilos por habitante (Censo Agricola, 1960, p. 73-75). Dessa forma, o consumo per capita de Minas Gerais em 1960 passaria de 29,3 para 38,1 quilos. Estes dados sugerem relativa estabilidade do nível de consumo de açúcar na primeira metade do século 20 e tendência de crescimento a partir da segunda metade da centúria. Este movimento está em perfeita sintonia com a aceleração da participação do açúcar de usina na produção mineira, que passa de $26 \%$ na safra de 1946-1947 para 56\% na safra de 1960-1961 e alcança $76 \%$ na safra de 1970-1971 (GODOY, 2004, p. 82-111). Em outros termos, entre o final da década de 1940 e o início do decênio de 1970, processa-se completa inversão na posição relativa da produção industrial ante a dos engenhos.

Confrontado com a estimativa de consumo per capita de açúcar para 1836, 45,4 quilos (Tabela 8), os dados do século 20 sugerem importantes transformações.

11 "Deve-se atentar para o fato de que, naquela época, era relativamente alto o consumo mineiro de açúcar per capita, de $25 \mathrm{~kg} / a n o$, que superava a média nacional (22,2 kg)” (Diagnóstico da Economia Mineira, 1968, volume V, p. 304).

12 "O ponto de estrangulamento do setor era, já a essa altura, a diminuta escala das usinas. A precariedade das redes de viação e disseminação geográfica do mercado constituiu razão da estrutura artesanal no setor açucareiro, manifestada pelo grande número de engenhos. A constância desses mesmos fatores só permitiu que se alcançasse o estádio industrial em níveis modestos” (Ibidem, p. 305).

13 "O consumo per capita de açúcar em Minas Gerais em relação aos principais estados da região Centro-Sul é baixo (29,3 kg/hab. em 1962) enquanto no Rio e São Paulo este foi de 43,3 e 70,4 kg/hab. respectivamente" (Ibidem, p. 313). 
Acredita-se que a evolução histórica da economia mineira e as consequiências do processo de modernização tecnológica do setor canavieiro do Brasil determinaram a desestruturação das bases de padrão de consumo que perdurou mais ou menos inalterado até a passagem do século 19 para a centúria seguinte. No Oitocentos devem ter prevalecido níveis muito elevados de consumo de açúcares em Minas Gerais, determinados por abundante oferta e dieta alimentar limitada a produtos regionais. A redução do consumo no Novecentos resultou de descompasso entre o crescimento da produção e a expansão demográfica regional, bem como de mudanças na dieta alimentar, em grande medida resultante da expressão crescente do consumo de produtos importados de outros Estados. Incapaz de atender à demanda interna, a rapadura e o açúcar de engenho passaram a conviver, e depois a sofrer a concorrência da produção usineira regional e de outros Estados. Assim, o elevado consumo sugerido pelos dados de 1836 deve ser entendido a partir de perspectiva de longo prazo e, sobretudo, segundo os atributos fundamentais, e praticamente imutáveis, da produção canavieira tradicional de Minas. Entretanto, o consumo de 45,4 quilos de açúcares de engenho por habitante estava bem aquém do que um século depois era entendido como o nível de consumo básico de açúcar. ${ }^{14}$ Depreende-se que a produção de Minas Gerais no século 19 atendia satisfatoriamente à necessidade de açúcar de sua população, e que a província apresentava níveis de consumo entendidos como pertinentes a sociedades de base urbano-industrial.

\section{UM SÉCULO DE PROEMINÊNCIA DO ESPAÇO CANAVIEIRO DE MINAS GERAIS}

Embora as estimativas refiram-se à década de 1830, existem evidências de que a posição de proeminência do espaço canavieiro de Minas Gerais tenha se constituído nos decênios anteriores. Salienta-se a histórica simetria entre crescimento demográfico e expansão da produção de derivados da cana (Ibidem, p. 22-111). No transcurso dos séculos 18 e 19, o mercado de Minas consumia quase exclusivamente a produção interna, assim como era inexpressiva a parcela da produção que se destinava a mercados externos. A desconcentração populacional e elevados custos dos transportes tendiam a esvaziar a importância das inovações técnicas sobre a produtividade e produção (Ibidem, p. 22-111). Assim, o ritmo de expansão do número de engenhos, da força de trabalho empregada e da produção caracterizava-se pela ausência de oscilações. Depreende-se que a proeminência do espaço canavieiro de Minas Gerais resultou de

14 Em 1940, Luís Amaral, ao criticar a orientação do Instituto do Açúcar e do Álcool ante o que considerava um falso problema - a suposta superprodução de açúcar das décadas de 1920-1930 - apresentou estimativa do que considerava o consumo per capita mínimo de açúcar: "Considerando-se que cada pessoa necessita de um minimo de 50 kilos de assucar por anno, conclue-se que munca houve superproducção de assucar no Brasil, mas, sim, formidável subconsumo” (AMARAL, 1940, p. 142-143). 
processo de crescimento regular e em perfeita consonância com as exigências do mercado interno da capitania, depois província. É provável que ulteriores investigações reúnam dados a sustentar que Minas possuía a mais importante economia canavieira do País bem antes da década de 1830 .

Mesmo que faltem evidências para determinar o momento em que as atividades agroaçucareiras mineiras assumiram importância incontrastável, não parece restar dúvida de que no último século de hegemonia das formas tradicionais de fabricação de açúcar o espaço canavieiro de Minas Gerais ocupou posição proeminente. Somente com o estabelecimento progressivo dos engenhos centrais e usinas e o correspondente crescimento da produção industrial, foi gradativamente diminuindo a distância entre Minas e os demais grandes espaços canavieiros do Brasil. O ritmo muito mais lento da modernização em Minas Gerais foi responsável pela perda de secular liderança na produção brasileira de açúcar. Enquanto em São Paulo, Rio de Janeiro e grandes espaços canavieiros do Nordeste a produção industrial superou a artesanal e a manufatureira já nas primeiras décadas do século 20, em Minas Gerais os engenhos responderam pela maior parte da produção até o início da década de 1950 (Ibidem, p. 82-111).

A modernização do setor canavieiro do Brasil caracterizou-se pelo lento crescimento da produção industrial, pela persistência da produção artesanal e manufatureira, pela assimetria espacial das transformações tecnológicas e pelo caráter conservador expresso na manutenção ou deterioração de estruturas sociais desiguais. $\mathrm{O}$ surgimento das unidades industriais, na segunda metade do Oitocentos, iniciou processo que se estenderia por quase um século. Apenas no final da década de 1920, as usinas superaram os engenhos na produção de açúcar (Ibidem, p. 82-111). Ainda na safra 1941-1942, as unidades artesanais e manufatureiras respondiam por um terço da produção brasileira de açúcar (Ibidem, p. 555).

A evolução da distribuição relativa da produção de açúcar em usinas e engenhos por Estados e para o Brasil, para as safras de 1937-1938 a 1941-1942, evidencia a referida assimetria espacial do processo de modernização do setor canavieiro (Ibidem, p. 556). As unidades industriais respondiam, em média, por mais de dois terços do açúcar fabricado no País, ou 68,4\%. Dentre os grandes espaços canavieiros do Brasil, apenas em Minas Gerais a produção industrial ainda era pouco expressiva ante a artesanal e manufatureira. A produção tradicional estava reduzida a posição quase insignificante no Rio de Janeiro e em Sergipe, médias de 5,3\% e 6,5\% respectivamente. Em Pernambuco e São Paulo, os engenhos ainda sustentavam participação algo importante, $11,9 \%$ e 13,3\%, respectivamente. Em Alagoas, a produção artesanal e manufatureira alcançava quase um quarto da produção, ou média de $23,6 \%$. Na Bahia, os engenhos perfaziam quase a metade da produção, ou média de 46,7\%. Em 
Minas, a produção tradicional respondia por mais de quatro quintos da produção do Estado, ou 83,2\% em média. Constata-se a estreita conexão entre a liderança do espaço canavieiro de Minas Gerais na primeira metade do século 19, que perdurou até o início da centúria seguinte, e o relativo atraso da modernização tecnológica das atividades agroaçucareiras do Brasil.

São muitas as evidências da posição proeminente das atividades agroaçucareiras de Minas no início do século 20. Os dados apresentados a seguir, referentes ao ano de 1920, possibilitam a comparação de vários índices respeitantes aos espaços canavieiros regionais do Brasil.

Minas Gerais respondia por quase um terço da área cultivada com cana-de-açúcar do Brasil $(30,1 \%)$. A soma da extensão territorial com cultivo da cana dos quatro principais espaços canavieiros do Nordeste (Pernambuco, Bahia, Sergipe e Alagoas) era inferior à mineira. A área cultivada dos Estados do Rio de Janeiro e São Paulo não alcançava a metade da mineira. Estava em Minas quase um terço dos produtores de cana-de-açúcar do Brasil (30,7\%). Os quatro mais importantes espaços canavieiros do Nordeste somavam número de produtores que correspondia à metade do existente em Minas Gerais. Os Estados do Rio de Janeiro e de São Paulo alcançavam participação relativa inferior a um terço da mineira. Eram regionalmente muito variáveis os níveis de produtividade de cana-de-açúcar por unidade de área cultivada, assim como muito diversa a média de cana por unidade de produção. Enquanto em Minas a produção média de cana por hectare era de 13,5 toneladas, a de Pernambuco perfazia 30,7 toneladas e a do Estado do Rio de Janeiro alcançava 72,1 toneladas. Enquanto em Minas Gerais a quantidade média de cana cultivada por produtor era de 73,3 toneladas, a do Rio de Janeiro montava a 229,2 toneladas e a de Pernambuco chegava a 493,6 toneladas. Ainda assim, a produção de cana-de-açúcar de Minas representava mais de um quinto da produção nacional $(20,1 \%)$ e superava a de todos os grandes espaços canavieiros do Brasil (Carteira Estatistica de Minas Geraes, 1929, p. 294 e 297).

A distribuição dos engenhos e usinas em 1920 reafirma a relativa lentidão do processo de modernização tecnológica de Minas Gerais ante os demais grandes espaços canavieiros do Brasil. Enquanto Pernambuco, Bahia, Sergipe, Alagoas, Rio de Janeiro e São Paulo somavam mais de $90 \%$ das unidades industriais do País, em Minas estavam apenas $2,1 \%$ das usinas brasileiras. Em contrapartida, a soma das unidades tradicionais dos espaços canavieiros acima mencionados não perfazia a participação relativa dos engenhos de Minas Gerais $(36,1 \%)$. Somadas usinas e engenhos, nenhum Estado apresentava número de proprietários de unidades transformadoras da cana que rivalizasse com o de Minas (Carteira Estatistica de Minas Geraes, 1929, p. 316). 
A produção de açúcar em engenhos e usinas salienta a assimetria do processo de modernização tecnológica das atividades agroaçucareiras do Brasil. Em 1920, entre os grandes espaços canavieiros do País, apenas em Minas Gerais a produção industrial de açúcar ainda era pouco expressiva $(6,1 \%)$. Em Alagoas, as usinas produziam 21,1\% do açúcar, em Sergipe perfaziam 35,1\%, em São Paulo alcançavam 45,7\%, na Bahia respondiam por $49,7 \%$, no Rio de Janeiro atingiam 56,1\% e em Pernambuco as usinas fabricavam $64,6 \%$. A soma da participação relativa destes Estados perfazia 93,9\% da produção brasileira de açúcar de usina. Mesmo diante da posição de atraso relativo no processo de modernização, a produção de açúcar de todos os tipos de Minas Gerais era inferior apenas à de Pernambuco e superava largamente a dos demais grandes espaços canavieiros (Carteira Estatistica de Minas Geraes, 1929, p. 316).

Na monografia $O$ Assucar, publicada em 1933, pela Secretaria da Agricultura de Minas Gerais, foram divulgados dados do Serviço de Inspeção e Fomento Agrícolas que divergem significativamente dos apresentados na Carteira Estatistica de Minas Geraes, com base em informações da Diretoria de Estatística. Segundo esta seção do Ministério da Agricultura, em 1920 o Brasil produziu 850.565 toneladas de "açúcar de todos os tipos", portanto 155.303 toneladas a mais do que os dados apurados pela Diretoria de Estatística do mesmo ministério. A distribuição regional destes dados colocava a produção mineira (180 mil toneladas) muito próxima da pernambucana (186 mil toneladas). Minas respondia por 21,2\% do açúcar fabricado no País, enquanto Pernambuco perfazia 21,9\%. A produção dos demais grandes espaços canavieiros estava assim distribuída: São Paulo 130 mil toneladas (15,3\%), Alagoas 68.690 toneladas $(8,1 \%)$, Rio de Janeiro 57.510 toneladas $(6,8 \%)$, Bahia 48 mil (5,6\%) e Sergipe 33 mil (3,9\%). Conquanto se desconheça a metodologia que presidiu o recolhimento das informações pelo Serviço de Inspeção e Fomento Agrícolas, as divergências parecem decorrentes da inclusão de parcela da produção tradicional omitida pela Diretoria de Estatística (O Assucar, 1933, p. 46-47).

Em 1920, a aguardente era o mais importante subproduto da cana-de-açúcar depois do açúcar, cabendo à produção de álcool participação muito menos expressiva. Minas Gerais era o maior fabricante nacional do destilado, com mais de um quinto da produção $(20,8 \%)$. Dos grandes espaços canavieiros, apenas os Estados de São Paulo $(17,6 \%)$ e Rio de Janeiro $(14,8 \%)$ apresentavam participação relativa que pudesse rivalizar com a mineira. A soma da produção de Pernambuco, Bahia, Alagoas e Sergipe não era muito maior do que a de Minas, alcançando pouco menos de um quarto da aguardente fabricada no Brasil $(24,3 \%)$. Como no caso da produção de açúcar, dentre os principais espaços canavieiros do País, apenas em Minas Gerais a produção industrial do destilado ainda era pouco expressiva $(1,2 \%)$. No Estado de São Paulo, as usinas e destilarias produziam 10,1\%, em Sergipe perfaziam 14,5\%, 
em Pernambuco eram de 21,4\%, em Alagoas atingiam 32,4\%, no Rio de Janeiro respondiam por $44,4 \%$ e na Bahia alcançavam $66,2 \%$. A soma da participação destes Estados perfazia $90,5 \%$ da produção brasileira de aguardente em usinas e destilarias (Carteira Estatistica de Minas Geraes, 1929, p. 316).

As evidências apresentadas demonstram a proeminência das atividades agroaçucareiras de Minas Gerais no início do século 20. Da comparação entre os grandes espaços canavieiros regionais resultou a constatação de que Minas ocupava posição de liderança na maior parte das variáveis: área cultivada com cana-de-açúcar, número de produtores de cana, produção de cana-de-açúcar, número de engenhos, número total de unidades transformadoras da cana, produção de açúcar em engenhos, produção de aguardente em engenhos, produção total de aguardente. Nas variáveis respeitantes exclusivamente à produção industrial, o desempenho de Minas Gerais era inexpressivo: número de usinas, produção de açúcar em usinas e produção de aguardente em usinas e destilarias. Na produção total de açúcar, Minas ocupava a segunda posição.

\section{O PRIMADO DO MERCADO INTERNO}

Duas reflexões de natureza historiográfica impõem-se a partir dos resultados alcançados. Em primeiro lugar, acredita-se necessário proceder a revisão da História do Açúcar no Brasil, notadamente em sua etapa anterior à modernização. As evidências apresentadas parecem suficientes para assinalar o lugar de destaque das atividades agroaçucareiras destinadas ao mercado interno. Muito mais do que produção de autoconsumo ou de restrita circulação vicinal, o segmento canavieiro orientado para o mercado interno não apenas atendia às necessidades de expressiva população, bem como sustentava níveis de consumo insuspeitados. Da mesma forma, é plausível considerar que o caso estudado seja não apenas a mais importante expressão desse segmento, mas também enuncia atributos pouco considerados pela historiografia, mormente a estreita conexão entre escravidão e mercado interno. A imagem, quase exclusivista, do engenho associado à grande lavoura escravista exportadora precisa ser substituída por percepção que contemple, da forma mais ampla possível, as muitas expressões de uma civilização do açúcar plural. Defende-se, em síntese, a vigência de dois grandes paradigmas de atividades agroaçucareiras no Brasil: paradigma agroexportador e paradigma mercados internos (GODOY, 2004, p. 23-80). Assim, é imprescindível, não apenas, que seja alargada a percepção das possibilidades de investigação, como igualmente urge considerar o imperativo de revisão de certas noções dominantes na historiográfica temática, que silencia, quando não desdenha, o desafio da compreensão da estrutura e a dinâmica do mercado interno brasileiro. 
Não se trata de esvaziar a importância dos estudos que sobrelevaram a importância do grande engenho exportador. Não se quer questionar a imprescindível presença de referências historiográficas no campo do paradigma agroexportador, como as obras de Gilberto Freyre (1961), de Stuart Schwartz (1988), de Vera Ferlini (1988) ou de Bert Barickman (2003). Propugna-se, ao contrário, pela efetivação de pesquisas que supram a relativa ausência de produção a contemplar o paradigma mercados internos.

O segundo desdobramento que se quer salientar é particular à discussão historiográfica sobre a História Econômica de Minas Gerais, especificamente no século 19. Os resultados apresentados reafirmam a pujança do mercado interno mineiro, sobretudo pelo vigor de atividade não-exportadora que dependia, em ponderável proporção, da utilização de trabalho escravo. Em outros termos, acredita-se que as atividades agroaçucareiras de Minas sejam emblemáticas de economia não estruturada segundo determinações exteriores e que, ao contrário, organizaram-se a partir de injunções próprias ao mercado interno da província, antes da capitania, e depois do Estado. Dessa forma, os resultados apresentados parecem robustecer a interpretação da economia mineira de Roberto Martins (1982), em especial ao salientar o primado do mercado interno na racionalidade econômica dos engenheiros mineiros. Também se entende que as evidências reunidas reafirmam a diversidade interna a Minas (PAIVA, 1996), a manifestar-se em importantes distinções regionais e a forjar padrão integrativo a sugerir divisão regional do trabalho. Ao sobrelevar as vinculações internas e esvaziar a importância das articulações, diretas ou indiretas, com o exterior, os resultados alcançados negam a validade de interpretação que buscou realçar o vigor do setor exportador de Minas e seus efeitos multiplicadores sobre o restante da economia (SLENES, 1985).

\section{REFERENNCIAS}

AMARAL, Luís. História geral da agricultura brasileira. São Paulo: Companhia Editora Nacional, 1939/40.

ARQUivo PÚBLICO MINEIRO: 1) Câmara Municipal de Ouro Preto CMOP487a; 2) Seção Provincial. Fazenda Provincial - SPFP3/1, diversas caixas; 3) Seção Provincial. Presidência da Província - SPPP1/49, caixas 11 e 13; 4) Seção Provincial. Presidência da Província. Mapas de Engenhos Aguardenteiros $e$ Casas de Negócio de 1836. SPPP 1/6, diversas caixas; 5) Seção Provincial. Presidência da Província. Mapas de população. Censo de 1831/32. SPPPl/10 e MP, diversas caixas; 6) Seção Provincial. Códice 149 - Secretaria do Governo Provincial, Registro de ofícios dirigidos pelo governo aos juízes da província, 
1836, páginas 143 verso e 144, circular solicitando a listagem de engenhos aguardenteiros e casas de negócio.

BURLAMAQUE, F. L. C. Monographia da canna d' assucar. Rio de Janeiro: Typographia de N. C. Vianna e Filhos, 1862.

CARTEIRA ESTATÍSTICA DE MINAS GERAES (EDIÇÃO DE 1929). Secretaria da Agricultura. Serviço de Estatística Geral. Belo Horizonte: Imprensa Oficial, 1929.

COSTA FILHO, Miguel. A cana-de-açúcar em Minas Gerais. Rio de Janeiro: Instituto do Açúcar e do Álcool, 1963.

COSTA, Iraci del Nero. Nota sobre a posse de escravos nos engenhos e engenhocas fluminenses (1778). Revista do IEB. São Paulo: IEB-USP, (28), p. 111-113, 1988.

BANCO DE DESENVOLVIMENTO DE MINAS GERAIS. Diagnóstico da Economia Mineira. Belo Horizonte: 1968. Volume V.

BARICKMAN, Bert Jude. Um contraponto baiano: açúcar, fumo, mandioca e escravidão no Recôncavo, 1780 - 1860. Rio de Janeiro: Civilização Brasileira, 2003.

EISENBERG, P. L. Modernização sem mudança-A indústria açucareira em Pernambuco, 1840-1910. Rio de Janeiro: Paz \& Terra - Unicamp, 1977.

FERLINI, Vera Lúcia Amaral. Terra, trabalho e poder: o mundo dos engenhos no Nordeste colonial. São Paulo: Brasiliense, 1988.

FREYRE, Gilberto. Nordeste: aspectos da influência da cana sobre a vida e a paisagem do Nordeste do Brasil. Rio de Janeiro: Livraria José Olympio Editora, 1961.

GODOY, Marcelo Magalhães. Intrépidos viajantes e a construção do espaço - Uma proposta de regionalização para as Minas Gerais do século XIX. Belo Horizonte: Cedeplar - UFMG, 1996 (Texto para Discussão n. 109).

. No pais das minas de ouro a paisagem vertia engenhos de cana e casas de negócio - Um estudo das atividades agroaçucareiras tradicionais mineiras, entre o Setecentos e o Novecentos, e do complexo mercantil da provincia de Minas Gerais. 2004. Tese (Doutorado) - FFLCH/USP. São Paulo.

INSTITUTO DO AÇÚCAR E DO ÁLCOOL - Anuário Açucareiro para o Ano de 1942. Rio de Janeiro: IAA, 1942.

INSTITUTO BRASILEIRO DE GEOGRAFIA E ESTATÍSTICA: 1) Anuário Estatístico do Brasil. Ano V - 1939/40. Rio de Janeiro: 1941; 2) Censo Agrícola de 1960. Rio de Janeiro: IBGE, 1960; 3) Censo Agropecuário de 1995/96. Rio de Janeiro: IBGE, 1996.

JACOB, Rodolpho. Minas Geraes no XX $X^{0}$ século. Rio de Janeiro: Gomes, Irmão \& C., 1911.

LIVRO DA LEI MINEIRA, 1836, Tomo II, Parte $1^{\mathrm{a}}$, Folha $\mathrm{n}^{\mathrm{o}} 5$. Lei $\mathrm{n}^{\circ}$ 49, 8/4/1836. Parte $2^{\text {a }}$, Folha $n^{\circ} 1$. Lei $n^{\circ} 49$, Regulamento $n^{\circ} 7,28 / 6 / 1836$. 
LOBO, Eulalia Maria Lahmeyer. História do Rio de Janeiro - do capital comercial ao capital industrial e financeiro. Rio de Janeiro: IBMEC, 1978.

MARTINS, Roberto Borges. A economia escravista de Minas Gerais no século XIX. Belo Horizonte: CEDEPLAR - UFMG, 1982 (Texto para Discussão, n. 10).

MATTOSO, Katia M. de Queirós. Babia, Século XIX - Uma provincia no Império. Rio de Janeiro: Editora Nova Fronteira, 1992.

MOTT, Luiz Roberto de Barros. Sergipe del Rey - População, economia e sociedade. Aracaju: Fundesc, 1986.

O ASSUCAR. Secretaria da Agricultura. Departamento de Estatística e Publicidade. Belo Horizonte: Oficinas Gráficas da Estatística, 1933.

PAIVA, Clotilde Andrade. População e economia das Minas Gerais do século XIX. 1996. Tese (Doutorado), FFLCH-USP. São Paulo.

; GODOY, Marcelo Magalhães. Território de contrastes: economia e sociedade das Minas Gerais do século XIX. In: SILVA, Francisco Carlos Teixeira; MATTOS, Hebe Maria; FRAGOSO, João (Org.). Escritos sobre história e educação, homenagem à Maria Yedda Leite Linhares, p. 479 - 515. Rio de Janeiro: Mauad e Faperj, 2001.

PETRONE, Maria Thereza S. A lavoura canavieira em São Paulo. São Paulo: Difusão Européia do Livro, 1968.

SANT'ANNA, Moacir Medeiros de. Contribuição à história do açúcar em Alagoas. Recife: IAA e Museu do Açúcar, 1970.

SILVA, José Joaquim da. Tratado de geografia descritiva especial da província de Minas Gerais. Belo Horizonte: Fundação João Pinheiro, 1997.

SILVA, Quintiliano José da. Fala dirigida à Assembléia Legislativa, 3/2/1846. Ouro Preto: Tipografia do Imparcial, 1846.

SLENES, Robert W. Os múltiplos de porcos e diamantes - a economia escravista de Minas Gerais no século XIX. Campinas: IFCH - UNICAMP, 1985. (Cadernos IFCH, n. 17).

SUBRINHO, Josué Modesto dos Passos. Reordenamento do trabalho - Trabalho escravo e trabalho livre no Nordeste açucareiro. Sergipe 1850 - 1930. Aracaju: Funcaju, 2000 .

SCHWARTZ, Stuart B. Segredos internos - engenhos e escrawos na sociedade colonial. São Paulo: Companhia das Letras, 1988. 